\title{
Astroglial Hemichannels and Pannexons: The Hidden Link between Maternal Inflammation and Neurological Disorders
}

\author{
Juan Prieto-Villalobos ${ }^{1}$, Tanhia F. Alvear ${ }^{1}$, Andrés Liberona ${ }^{1}{ }^{10}$, Claudia M. Lucero ${ }^{2}$, Claudio J. Martínez-Araya ${ }^{1}$, \\ Javiera Balmazabal ${ }^{1}$, Carla A. Inostroza ${ }^{1}$, Gigliola Ramírez ${ }^{1}$, Gonzalo I. Gómez ${ }^{2}$ (D) and Juan A. Orellana ${ }^{1, *(D)}$ \\ 1 Departamento de Neurología, Escuela de Medicina and Centro Interdisciplinario de Neurociencias, \\ Facultad de Medicina, Pontificia Universidad Católica de Chile, Santiago 8330024, Chile; \\ jcp.villalobos@gmail.com (J.P.-V.); tanhia.alvears@utem.cl (T.F.A.); andes.rojas.liberona@uc.cl (A.L.); \\ cmartineza@utem.cl (C.J.M.-A.); javi.balma24@gmail.com (J.B.); c.inostrozavenegas@gmail.com (C.A.I.); \\ gigliolaramirez@hotmail.com (G.R.) \\ 2 Institute of Biomedical Sciences, Faculty of Health Sciences, Universidad Autónoma de Chile, \\ Santiago 8910060, Chile; claulucerom@gmail.com (C.M.L.); gonzalo.gomez@uautonoma.cl (G.I.G.) \\ * Correspondence: jaorella@uc.cl; Tel.: +56-23548105
}

Citation: Prieto-Villalobos, J.; Alvear T.F.; Liberona, A.; Lucero, C.M.; Martínez-Araya, C.J.; Balmazabal, J.; Inostroza, C.A.; Ramírez, G.; Gómez, G.I.; Orellana, J.A. Astroglial Hemichannels and Pannexons: The Hidden Link between Maternal Inflammation and Neurological Disorders. Int. J. Mol. Sci. 2021, 22, 9503. https://doi.org/10.3390/ ijms22179503

Academic Editor: Mathieu Vinken

Received: 5 August 2021

Accepted: 30 August 2021

Published: 1 September 2021

Publisher's Note: MDPI stays neutral with regard to jurisdictional claims in published maps and institutional affiliations.

Copyright: (C) 2021 by the authors Licensee MDPI, Basel, Switzerland. This article is an open access article distributed under the terms and conditions of the Creative Commons Attribution (CC BY) license (https:// creativecommons.org/licenses/by/ $4.0 /)$.

\begin{abstract}
Maternal inflammation during pregnancy causes later-in-life alterations of the offspring's brain structure and function. These abnormalities increase the risk of developing several psychiatric and neurological disorders, including schizophrenia, intellectual disability, bipolar disorder, autism spectrum disorder, microcephaly, and cerebral palsy. Here, we discuss how astrocytes might contribute to postnatal brain dysfunction following maternal inflammation, focusing on the signaling mediated by two families of plasma membrane channels: hemi-channels and pannexons. $\left[\mathrm{Ca}^{2+}\right]_{\mathrm{i}}$ imbalance linked to the opening of astrocytic hemichannels and pannexons could disturb essential functions that sustain astrocytic survival and astrocyte-to-neuron support, including energy and redox homeostasis, uptake of $\mathrm{K}^{+}$and glutamate, and the delivery of neurotrophic factors and energyrich metabolites. Both phenomena could make neurons more susceptible to the harmful effect of prenatal inflammation and the experience of a second immune challenge during adulthood. On the other hand, maternal inflammation could cause excitotoxicity by producing the release of high amounts of gliotransmitters via astrocytic hemichannels/pannexons, eliciting further neuronal damage. Understanding how hemichannels and pannexons participate in maternal inflammation-induced brain abnormalities could be critical for developing pharmacological therapies against neurological disorders observed in the offspring.
\end{abstract}

Keywords: connexins; pannexins; hemichannels; pannexons; neuroinflammation; lipopolysaccharide; neuron; astrocyte; microglia; neurodegeneration; excitotoxicity

\section{Introduction}

Clinical evidence has established that environmental clues acting at specific windows during fetal development affect lifelong trajectories across health and disease [1]. Such "programming" encompasses a physiological and adaptive process that sculpts the structure and function of different tissues at the stage when they are most plastic due to the proliferation and differentiation of progenitor cells [2]. Nevertheless, negative geneenvironment interactions linked to perinatal disease, either maternal or fetal, disrupt this physiological programming, which increases individual susceptibility to develop complex diseases from birth to adult life [3]. For instance, maternal immune perturbations during pregnancy, either in response to infections or noninfectious stimuli (e.g., diabetes, stress, maternal allergic asthma, obesity, or toxin exposures), cause enduring or later-in-life alterations of the offspring brain structure and function [4]. The latter increases the risk of developing several psychiatric and neurological disorders, including schizophrenia, 
intellectual disability, bipolar disorder, autism spectrum disorder (ASD), microcephaly, and cerebral palsy [5] (Figure 1).

Although the study of Karl A. Menninger and later on the work of Torrey and Peterson were pioneering in revealing the association between viral infection and subsequent psychotic disease [6,7], it was Mednick et al. (1988) who showed that maternal influenza enhances the incidence of schizophrenia in the offspring [8]. Thenceforth, similar findings have been observed with other viral (e.g., cytomegalovirus, herpes simplex virus type 2, varicella-zoster and polio), bacterial (e.g., sinusitis, tonsillitis, pneumonia, and pyelonephritis), and parasite (e.g., toxoplasmosis) infections $[9,10]$. In the same line, other studies have connected rubella and cytomegalovirus infection during pregnancy with increased risk of ASD in the offspring [11,12], whereas cerebral palsy in adulthood associates with maternal infections $[13,14]$. Although less well understood and studied, intellectual disability and bipolar disorder correlate with bacterial and Toxoplasma gondii infection, respectively, during pregnancy $[15,16]$. Recent studies have hypothesized that prenatal exposure to SARS-CoV-2, the virus that causes the coronavirus disease 2019 (COVID-19), could augment the incidence of psychosis, schizophrenia, and schizophrenia spectrum disorders in the offspring [17].

Although epidemiological research provides a strong link between prenatal life and adult neurological disease risk, its efficiency in deciphering the concomitant downstream cellular and molecular mechanisms is limited for ethical or technical reasons. Thus, the vast amount of knowledge gathered to date about maternal inflammation that results in offspring brain abnormalities comes from experimental studies in rodents (for a comprehensive review, see [18]). Most of them have used the systemic administration of lipopolysaccharide (LPS) or polyriboinosinic-polyribocytidilic acid [poly (I:C)] during pregnancy [18]. LPS, the major component of the outer membrane of Gram-negative bacteria, is a well-known, established bacterial infection model, which leads principally to cytokine production, inflammation, fever, complement cascade activation, hypothalamicpituitary-adrenal axis activation, and sickness behavior [19]. At the other end, poly (I:C) is a synthetic analog of double-stranded RNA that efficiently mimics the acute phase response to viral infection, including the production and release of interleukin (IL)- $1 \beta$, IL-6, and tumor necrosis factor (TNF)- $\alpha$, as well as the induction of the type I interferons (IFNs): IFN- $\alpha$ and IFN- $\beta$ [20]. Several studies using these immunogenic approaches have demonstrated that maternal inflammation impairs normal behavior and social interactions in adult progeny [21-25] (Figure 1). The latter includes a decline in learning and memory, increased anxiety-like and repetitive behaviors, motor deficits, and disturbed exploratory performance [21,25-29].

There is a certain consensus that a common pathogenic pathway linked to cytokinemediated inflammation disrupts fetal brain development and adult central nervous system (CNS) maturation following maternal disease $[4,30,31]$. Coherent with this notion, human epidemiological evidence indicates that high gestational levels of IL- $1 \alpha$, IL-6, IL-8, IFN- $\gamma$, TNF- $\alpha$, granulocyte macrophage colony-stimulating factor, and C-reactive protein augment the incidence of schizophrenia and ASD in the progeny [32-34] (Figure 1). This evidence harmonizes with the critical role of IL- $1 \beta$ and IL-17 A on adult brain abnormalities observed following maternal immune activation in rodents $[35,36]$. In fact, in the absence of a pathogenic agent, the administration of IL-6 during pregnancy is sufficient to promote multiple behavioral and cognitive abnormalities in the offspring [37]. Despite the significant similarities between the inflammatory responses induced by several models of maternal inflammation [38-40], they also have differential immune signatures and specific pathophysiological responses that impact brain development, structure, and function $[4,18,26]$. For instance, unlike LPS, poly (I:C) is a potent activator of type I IFNs (e.g., IFN- $\beta$ ) and consequent antiviral immune responses [20], whereas LPS is more proficient in inducing the production and release of TNF- $\alpha$ from macrophages [41]. This predilection of LPS for TNF- $\alpha$ instead type I IFN signaling could explain why this endotoxin is more robust than poly (I:C) in provoking anorexia, lethargy, and fever [42]. 
The myriad of inflammatory factors produced by infections or noninfectious pathological stimuli during gestation induces diverse pathophysiological processes in the maternal, placental, and fetal compartments [4]. Part of these mediators can cross the blood-placental barrier, triggering systemic fetal inflammation and oxidative stress [43] and affecting the brain, with potentially damaging consequences for neuronal and glial cell function, synaptic transmission and plasticity, and behavior [44]. In the CNS, the innate immune system integrates these complex immune responses, whose central member is the microglia. These cells are the first line of defense against internal or external agents that resist or resolve harmful threats to restore homeostasis [45]. The role of microglia in fetal programming and postnatal brain abnormalities has been extensively studied [46-50]; however, the implication of other crucial glial populations involved in neuroinflammation remains elusive: the astrocyte [51]. Here, we discuss how astrocytes might contribute to postnatal brain dysfunction following maternal inflammation, focusing on the signaling pathways mediated by two families of plasma membrane channels: hemichannels and pannexons.

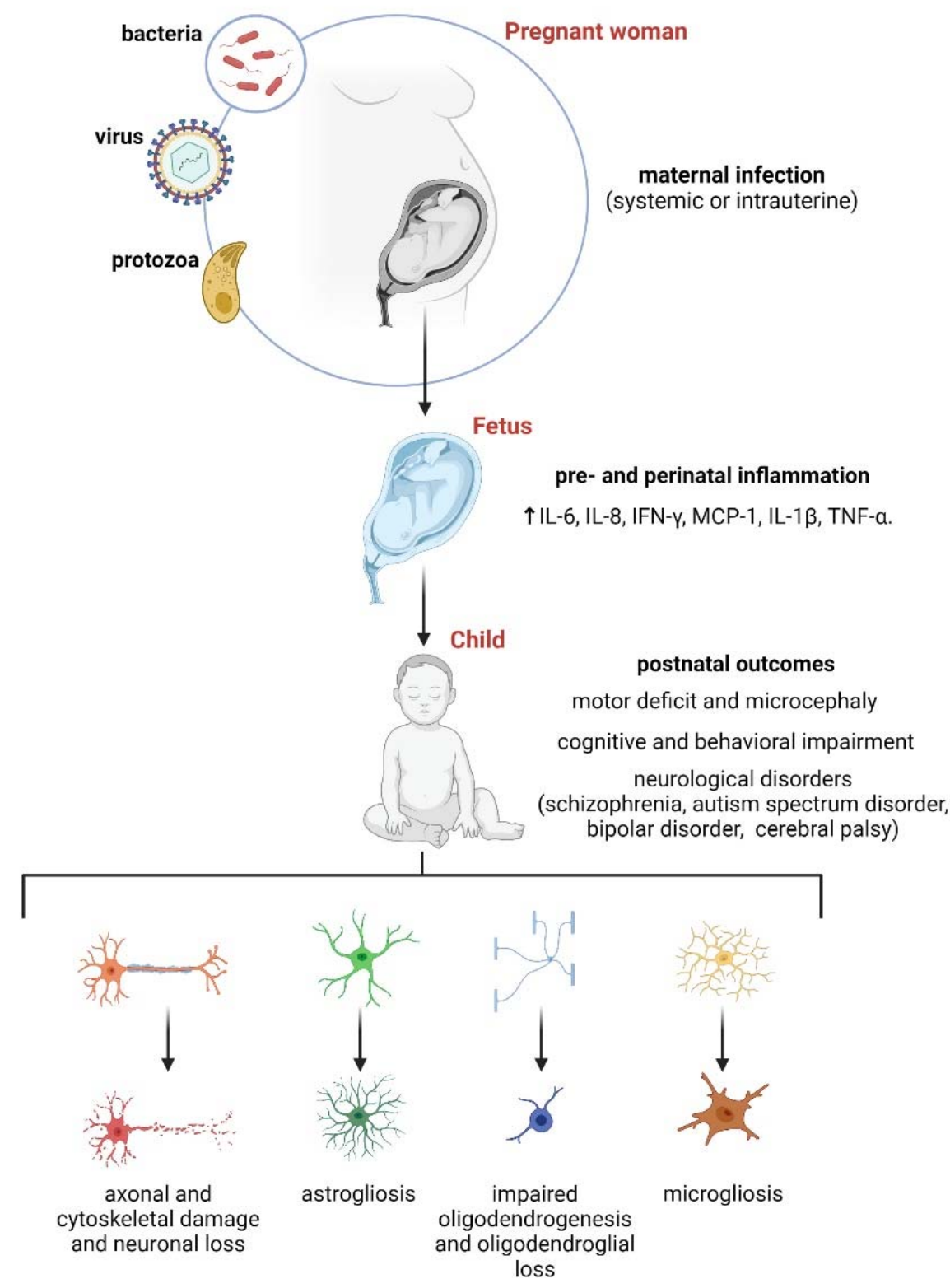

Figure 1. Schematics showing general aspects of maternal infection and its contribution to offspring brain abnormalities. Diverse infectious agents such as viruses (e.g., influenza), bacteria (e.g., E. coli), or protozoa (e.g., Toxoplasma gondii) can induce systemic or intrauterine maternal inflammation. 
The latter occurs in parallel with the activation of placental cytokine receptors and immune cell infiltration, with both phenomena being crucial for pre and perinatal fetal brain inflammation. Cytokine-mediated inflammation at this stage causes severe consequences for fetal brain development and potentially elicits diverse postnatal CNS alterations, including neuronal damage [52,53], reactive astrogliosis and microgliosis $[48,51]$, and impaired oligodendrogenesis and oligodendroglial loss $[54,55]$. Certainly, fetal brain injury caused by the pathogens above increases the postnatal risk of developing motor deficits, microcephaly, and cognitive and behavioral impairment. In addition, multiple neurological disorders associate with prenatal inflammation: schizophrenia, autism spectrum disorder, bipolar disorder, and cerebral palsy.

\section{Astrocytes: Emerging Stars in the Healthy and Diseased Brain}

Mounting evidence in the last decades has refuted the notion that astrocytes act as simple fostering and buffering elements in the CNS [56]. Intracellular $\mathrm{Ca}^{2+}\left(\left[\mathrm{Ca}^{2+}\right]_{i}\right)$ waves within and among astrocytes encompass a time-scale mechanism for allowing rapid intraand inter-cellular signaling at different hierarchies [57-60]. These processes begin with the extracellular influx of $\mathrm{Ca}^{2+}$ via ion channels and through $\mathrm{Ca}^{2+}$ release from intracellular stores, causing $\left[\mathrm{Ca}^{2+}\right]_{i}$ transients that vary in frequency, kinetic and spatial spread according to the astrocyte anatomical zone [61]. Braced with this equipment and in the companion of pre- and postsynaptic neurons, astrocytes constitute the "tripartite synapse" - the angular stone of the chemical synaptic transmission-where they monitor neurotransmission and react to it by the $\left[\mathrm{Ca}^{2+}\right]_{\mathrm{i}}$-dependent release of signals that control neuronal activity termed "gliotransmitters" (i.e., glutamate, D-serine, and ATP) [62]. Accordingly, astrocytes seem crucial for synaptic transmission and plasticity, and learning and memory consolidation [63].

Furthermore, during high neuronal activity, astrocytes produce $\left[\mathrm{Ca}^{2+}\right]_{\mathrm{i}}$ signals that spread locally in networks in the form of $\left[\mathrm{Ca}^{2+}\right]_{i}$ waves that reach specialized astrocytic terminal processes or "endfeet" that contact the vasculature [64]. There, vasoactive messengers are released, allowing astrocytes to regulate the cerebral blood flow and exchange of energy-rich metabolites, with potentially significant consequences for neuronal firing, synaptic plasticity and higher brain functions [65]. In particular, astrocytic endfeet takes up glucose and distributes it among astrocytes through intercellular connections termed gap junctions [66]. Depending on neuronal energy demand, glucose can be stored in the form of glycogen or used by the astrocyte in glycolysis, being the resulting pyruvate converted to lactate and then released into the extracellular space [67]. Then, neurons can take up this lactate, convert it into pyruvate, and utilize it in aerobic respiration within the mitochondria [68] or take up directly glucose from the interstitial space and generate ATP from glycolysis and oxidative metabolism [69]. In addition, astrocytes participate in the innate immune response and govern the homeostasis of the brain interstitial fluid, supplying neurons with precursors for biosynthesis, controlling $\mathrm{pH}$ and $\mathrm{K}^{+}$homeostasis and recycling glutamate, oxidized scavengers, and other waste products [70].

Given that neurons are particularly susceptible to the action of free radicals and reactive oxygen species (ROS) [71,72], astrocytes protect them from this not only by providing an extensive array of antioxidant molecules and ROS-detoxifying enzymes (e.g., glutathione, superoxide dismutase, and glutathione peroxidase) but also through the direct transference of their healthy mitochondria, as well as the degradation of axonal mitochondria $[73,74]$. Astrocytes require an efficient $\left[\mathrm{Ca}^{2+}\right]_{i}$ regulation mechanism to fulfill their synaptic, metabolic, and homeostatic roles [60]. In this matter, the function of astrocyte mitochondria seems to be pivotal [75]. Along with serving as a source of ATP to fuel several $\mathrm{Ca}^{2+}$ pumps that keep low the $\left[\mathrm{Ca}^{2+}\right]_{i}$, mitochondria can also actively import $\mathrm{Ca}^{2+}$. The membrane potential associated with the proton electrochemical gradient across the inner mitochondrial membrane $(\sim 180-200 \mathrm{mV})$ facilitates the import of $\mathrm{Ca}^{2+}$ into the mitochondria against its concentration gradient via a $\mathrm{Ca}^{2+}$ uniporter protein [76]. Moreover, mitochondria can release $\mathrm{Ca}^{2+}$ from its matrix towards the cytosol via the mitochondrial $\mathrm{Na}^{+} / \mathrm{Ca}^{2+}$ exchanger [77] and the opening of the mitochondrial permeability 
transition pore [78]. Mitochondria serve as both sink and source of $\mathrm{Ca}^{2+}$ in astrocytes, thereby regulating the frequency, amplitude, and half-life of $\mathrm{Ca}^{2+}$ transient events in their cytoplasmic processes with significant potential consequences for astroglial signaling and function $[75,79,80]$.

Under pathological conditions, astrocytes experience a long-lasting morphological, molecular, and functional change referred to as "reactive astrogliosis", which is characterized by cytoskeletal rearrangements, hypertrophy, increased expression of the glial fibrillary acidic protein (GFAP), loss of structural complexity, metabolic alterations, and release of inflammatory mediators [81]. While this process is an adaptive mechanism necessary for limiting acute injury and favoring wound repair, when persistent, it can turn into a detrimental response if astrocytes neglect their supportive role toward neurons [82]. Reactive astrogliosis becomes dysfunctional when damage is intense and chronic and usually negatively impacts different astrocyte aspects such as gliotransmission, $\mathrm{Ca}^{2+}$ signaling, mitochondrial function, antioxidant defense, and inflammatory response and survival [83].

\section{Maternal Inflammation and Its Impact on Astrocytes}

Clinical and animal studies have revealed that maternal inflammation causes different morphological and functional alterations on astrocytes. For instance, necrosis observed in periventricular leukomalacia, a brain injury that induces cerebral palsy, likely via maternal infection [84], correlates with increased GFAP and IFN- $\gamma$ expression in astrocytes, as well as nitrosative and oxidative damage $[85,86]$. Consistent with this, maternal LPS administration accentuates offspring astrogliosis in the hippocampus, cortex, amygdala, hypothalamus, thalamus, and white matter, associated with hypomyelination [87-91]. Likewise, long-lasting astrogliosis takes place in the hippocampus of mice prenatally exposed to the human influenza virus [92], and similar findings have been observed following poly (I:C)-induced maternal immune activation [93-96]. Despite the latter, other studies have described that prenatal poly (I:C) exposure does not affect the astroglial number and expression of GFAP in the offspring [97-100]. These apparent discrepancies between the studies mentioned above make sense in the light of at least two crucial factors. Firstly, astrogliosis is biologically complex and cannot be reduced to the expression of one marker, which is significant, considering that $\mathrm{GFAP}^{+}$astrocytes represent just a fraction of the total astroglial population with a substantial regional (and probably developmental) heterogeneity [101]. In addition, counting GFAP ${ }^{+}$astrocytes illustrates presumably GFAP expression alterations rather than valid changes in astrocyte number. At the other end, the experimental design of poly (I:C)-induced maternal inflammation differs considerably among studies, with different doses, administration routes, and gestational time points of exposure. These factors undoubtedly change the fetal niche to different degrees, affecting the outcome of astroglial function and reactivity significantly.

Alterations to morphology and number of astrocytes occur in the offspring of animals exposed to other stressors or challenges during pregnancy, including (but not exclusively) IL-6 [53], perfluorooctane sulfonate [102], stress [103,104], ischemia [105], dexamethasone [106], ethanol [107], carbon black nanoparticles [108], and high-fat diet [109,110]. Some studies have shed light on possible mechanisms explaining how astrocytes may contribute to prenatal life-induced programming of the brain. For example, Zhang and colleagues demonstrated that prenatal LPS exposure produces prolonged glutamate elevation in periventricular white matter in the progeny associated with astroglial hypertrophy and decreased glial L-glutamate transporter 1 [46]. On the other hand, prenatal stress increases astroglial death and GFAP expression, accompanied by elevated production of fractalkine and nitric oxide (NO) [104]. Both studies harmonize with previous data indicating that glutamate and NO released by astrocytes impair neuronal function and survival [111-113]. More recently, two studies have suggested that maternal inflammation-induced brain abnormalities in adulthood depend on the persistent activation of two families of large-pore plasma membrane channels in astrocytes: hemichannels and pannexons. 


\section{Hemichannel and Pannexons: Protagonists on Astroglial Physiology and Pathophysiology}

In the last decade, other research groups and we have described that hemichannels and pannexons, two families of plasma membrane channels, may alter different aspects of astroglial function with potentially significant consequences for neuronal function during pathological conditions [111,112,114-122]. Hemichannels result from the oligomerization of six protein subunits called connexins around a central pore [123] (Figure 2). Connexins encompass a highly conserved protein family encoded by 21 genes in humans and 20 in mice, with orthologs in other vertebrate species [124]. For a considerable time, the essential function ascribed to hemichannels was to constitute the basic components of the gap junctions, these being aggregates of intercellular channels that provide the direct but selective molecular and ionic exchange between the cytoplasm of contacting cells [125] (Figure 2). Notwithstanding, in the $90 \mathrm{~s}$, groundbreaking findings by Paul and colleagues revealed the presence of functional and solitary hemichannels in "non-junctional" membranes [126]. Nowadays, it is well-established that these channels act like permeable pores, providing a diffusional route for the release of relevant quantities of autocrine and paracrine signaling molecules (e.g., ATP, glutamate, D-serine, $\mathrm{NAD}^{+}$, and $\mathrm{PGE}_{2}$ ) as well as the influx of other substances (i.e., $\mathrm{Ca}^{2+}, \mathrm{cADPR}$, and glucose) [123] (Figure 2).
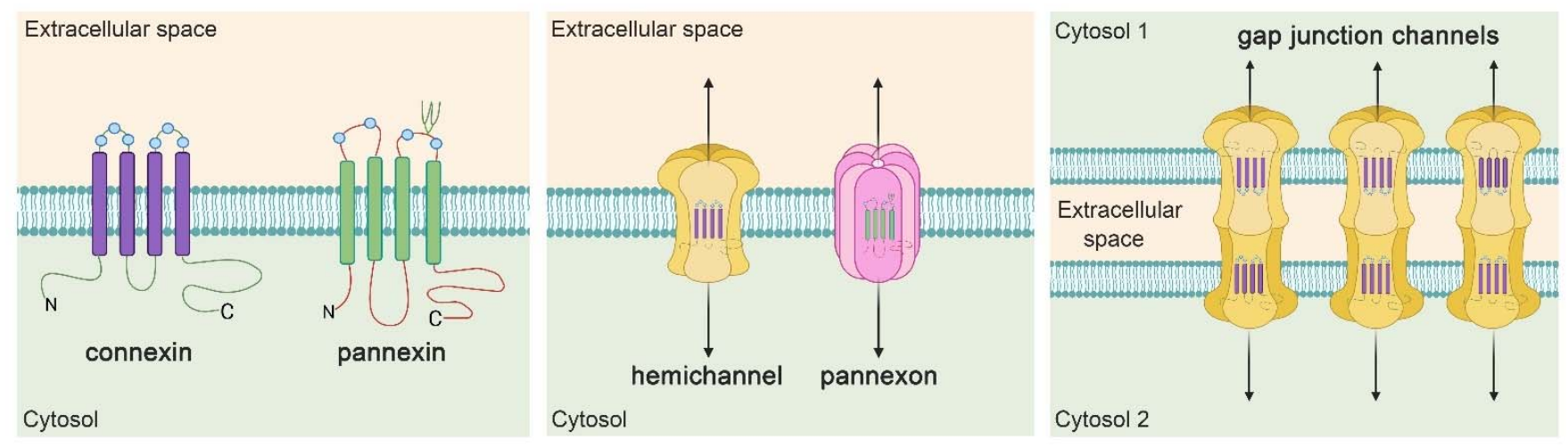

Figure 2. The general structure of connexin- and pannexin-based channels. Connexins and pannexins share a similar membrane topology with four $\alpha$-helical transmembrane domains connected by two extracellular loops and one cytoplasmic loop; both the amino- and carboxy-termini are intracellular (left panel). The relative positions of the extracellular loop cysteines (blue light balls) and glycosylated asparagine (green branches) are also showed. Hemichannels (also known as connexons) are formed by the oligomerization of six subunit connexins around a central pore, whereas pannexons are constituted of seven pannexin subunits (middle panel). Both channels underpin the ionic and molecular interchange between the intra- and extracellular milieu. In addition, hemichannels dock each other to build intercellular channels termed gap junction channels (right panel). These channels aggregate in anatomical structures called gap junctions to support the intercellular cytoplasmic exchange of metabolites, second messengers, and ions.

Two decades ago, a novel family of three membrane proteins called pannexins (Panxs 1-3) was discovered, with the ability to constitute single membrane channels (also known as pannexons) that connect the cytosol with the interstitial space [127]. Even though hemichannels and pannexons belong to a broad family of large-pore channels [128], they diverge in terms of permeability and conductance, as well as gating and posttranslational mechanisms that modulate them $[129,130]$. Consistent with this idea, both channels remain fully functional under resting membrane potentials [131,132], displaying large membrane currents after depolarization [126,131]. Unlike hemichannels, pannexons produce peak current amplitudes with fast kinetics and show larger unitary conductance, weak voltage-gating, and diverse subconductance states [126,131,133-136]. Similarly, hemichannel activity is significantly modulated by the extracellular concentration of divalent cations [137], whereas gating properties of pannexons remain insensitive to external $\mathrm{Ca}^{2+}[133,138]$. 
Connexin 43 (Cx43) constitutes the most ubiquitous connexin expressed by astrocytes [139]. Astrocytes also exhibit appropriate levels of Panx1, and both Cx43 and Panx1 form functional astroglial hemichannels and pannexons, respectively, on in vitro and ex vivo preparations [118,140-143]. Cellular signaling and gliotransmitter release via the opening of astrocytic hemichannels and pannexons underpin relevant biological processes at the nervous system, including neuronal oscillations [144], astroglial migration [145], food intake [146], synaptic transmission, and plasticity [132,147-149], as well as memory consolidation and behavior [150,151] (Figure 3). Despite the above, the uncontrolled activation of these channels in astrocytes associate with the pathogenesis and progression of homeostatic imbalance in various neuropathological diseases [111,112,114-122]. The nature of the pathological agents linked to the opening of astroglial hemichannels/pannexons is multiple, including cytokines [152], amyloid- $\beta$-peptide [111], $\alpha$-synuclein [121], ethanol [122], anticonvulsants drugs [153], ultrafine carbon black particles [154], and oxidant stress [155]. At least three mechanisms have linked the persistent opening of hemichannels and pannexons with cell dysfunction and damage. At one end, the uncontrolled entry of $\mathrm{Na}^{+}$and $\mathrm{Cl}^{-}$through hemichannels may result in osmotic and ionic imbalances linked to further cell swelling and plasma membrane breakdown [126,156] (Figure 3). Relevantly, hemichannels are permeable to $\mathrm{Ca}^{2+}[157,158]$, which could allow its influx to the cytosol during pathological conditions. In the same line, Panx1 channels release ATP to the interstitial space, which activates purinergic receptors, causing the entry of extracellular $\mathrm{Ca}^{2+}$ or its release from intracellular stores [159]. The direct or indirect increase in $\left[\mathrm{Ca}^{2+}\right]_{\mathrm{i}}$ mediated by hemichannels/pannexons could lead to $\mathrm{Ca}^{2+}$ overload and consequent induction of different proteases, phospholipases, and other hydrolytic enzymes, as well as oxidative stress and caspase activation $[119,160]$. Last but not least, exacerbated hemichannel/pannexon activity may trigger the release of high amounts of molecules potentially toxic for neighboring cells, such as glutamate, in the case of the CNS [111,112] (Figure 3).
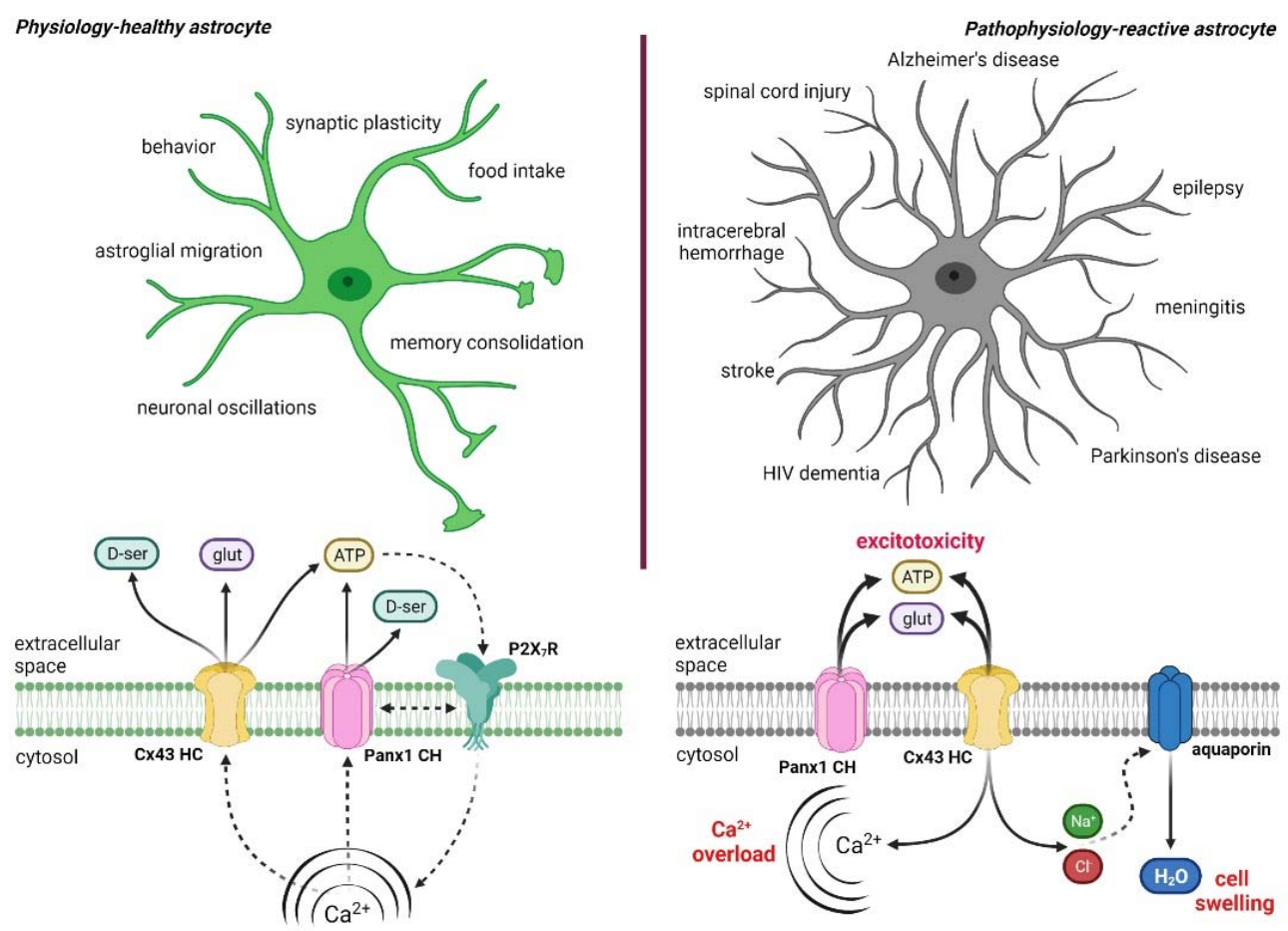

Figure 3. Physiological and pathophysiological roles of astrocytic Cx43 hemichannels and Panx1 channels in the CNS. The top left panel represents a healthy astrocyte (in green) under physiological conditions. In this context, the physiological release of gliotransmitters (glutamate, D-serine, and ATP) via astrocytic $\mathrm{C} \times 43$ hemichannels and Panx1 channels, along with $\left[\mathrm{Ca}^{2+}\right]_{\mathrm{i}}$ and purinergic 
receptor signaling, contributes to diverse biological brain processes (bottom left panel), including synaptic plasticity [132,147-149], neuronal oscillations [144], food intake [146], astroglial migration [145], fear memory consolidation [151], and behavior [150]. The top right panel shows a reactive astrocyte (in gray) in a pathophysiological scenario. Here, reactive astrogliosis depicted by hypertrophy of cellular processes is accompanied by persistent and exacerbated opening of Cx43 hemichannels and Panx1 channels in astrocytes (bottom right panel). The latter likely leads to cellular damage and dysfunction by different mechanisms. For example, $\mathrm{Ca}^{2+}$ influx via $\mathrm{Cx} 43$ hemichannels might activate phospholipase $\mathrm{A}_{2}$ and subsequently elicit the production of arachidonic acid and stimulation of the cyclooxygenase/lipoxygenase pathway. This response could then increase levels of free radicals, lipid peroxidation, and plasma membrane damage. In addition, $\mathrm{Na}^{+}$and $\mathrm{Cl}^{-}$entry via Cx43 hemichannels/Panx1 channels could trigger cellular swelling due to a boosted influx of $\mathrm{H}_{2} \mathrm{O}$ via aquaporins. At the other end, the massive release of gliotransmitters via astrocytic $\mathrm{Cx} 43$ hemichannels and Panx1 channels might reduce the viability and function of healthy neighboring neurons. Indeed, a substantial body of evidence indicates that these channels contribute to the development of multiple CNS disorders and diseases, including Alzheimer's disease [119,161], epilepsy [162,163], meningitis [116], Parkinson' disease [121], HIV-induced dementia [164,165], stroke [166,167], intracerebral hemorrhage [168], and spinal cord injury [117,169]. Solid lines depict fluxes of molecules through channels, whereas dashed lines indicate activation or induction.

\section{Connecting Maternal Inflammation with the Activation of Hemichannels and Pannexons in Offspring Astrocytes}

Avendaño and collaborators were pioneers in demonstrating that LPS administration during pregnancy augments the activity of Cx43 hemichannels and Panx1 channels in neonatal astrocytes cultures [170]. How could LPS trigger the opening of these channels in the context of fetal programming? As mentioned above, maternal administration of LPS causes an acute phase of systemic inflammation that goes hand in hand with the production of placental inflammatory mediators, which occurs at crucial developmental stages of the fetal brain [43]. Although LPS induces the activation of Cx43 hemichannels in cultured astrocytes and C6 glioma cells [152,171], the ability of prenatal LPS exposure to promote the opening of these channels likely relies on downstream interactions of cytokines with placental receptors, which significantly and permanently affect the structure and functional capacity of the fetal brain. Accordingly, prenatal LPS-induced activation of Cx43 hemichannels and Panx 1 channels is mitigated by the inhibition of IL- $1 \beta /$ TNF- $\alpha$ signaling and accompanied by high autocrine production of astroglial IL-1 $\beta /$ TNF- $\alpha$ [170]. The latter agrees with the fact that both cytokines directly: (i) enhance ion currents mediated by astrocytic Cx43 hemichannels [152] and (ii) modulate the uptake of cationic molecules via these channels [172]. Relevantly, the cytokine-mediated cell influx of small molecules is dependent on the properties of the permeant species (e.g., ethidium, 2-NBDG, DAPI) [172]. Altogether this evidence suggests that maternal exposure to LPS modifies the in utero fetal brain environment, and thus, it shapes the function of astroglial hemichannels and pannexons in the offspring. Although certainly connexins are controlled by epigenetics [173], the involvement of DNA methylation, histone acetylation, or microRNA regulation in the above phenomenon remains largely ignored.

Is there another source, besides astrocytes, for the production of IL-1 $\beta /$ TNF- $\alpha$ following maternal inflammation? Recently, it was revealed that microglia via the above cytokines elicit the prenatal LPS-mediated activation of astrocyte Cx43 hemichannels and Panx1 channels [174]. This evidence comes from experiments showing the ameliorative effect of minocycline, a molecule that mitigates microglial activation, or inhibition of IL-1 $\beta /$ TNF- $\alpha$ signaling, in the long-lasting opening of these channels in offspring hippocampal astrocytes [174]. These data are coherent with previous studies revealing that the LPS-mediated release of IL- $1 \beta$ and TNF- $\alpha$ from microglia promotes the activation of astroglial Cx43 hemichannels in vitro and ex vivo [114,152]. IL-1 $\beta / \mathrm{TNF}-\alpha$ signaling in astrocytes activates p38 mitogen-activated protein kinase (p38 MAPK), resulting in the expression of the inducible NO synthase (iNOS) and further NO production $[175,176]$. 
In agreement with this, blockade of p38 MAPK or iNOS strongly prevents the enhanced astrocyte hemichannel/pannexon activity observed in neonatal cultures or adult brain slices from prenatally LPS-exposed offspring $[170,174]$. The NO-mediated S-nitrosylation of Cx43, a posttranslational modification that opens Cx43 hemichannels [155], might play a fundamental role in this phenomenon as iNOS expression and production of NO show increments in astrocytes from the offspring of LPS-exposed dams $[170,174]$ (Figure 4). This evidence also agrees with the higher production of IL-1 $\beta$, TNF- $\alpha$, and NO found in the brain of prenatally LPS-exposed offspring $[18,177,178]$.

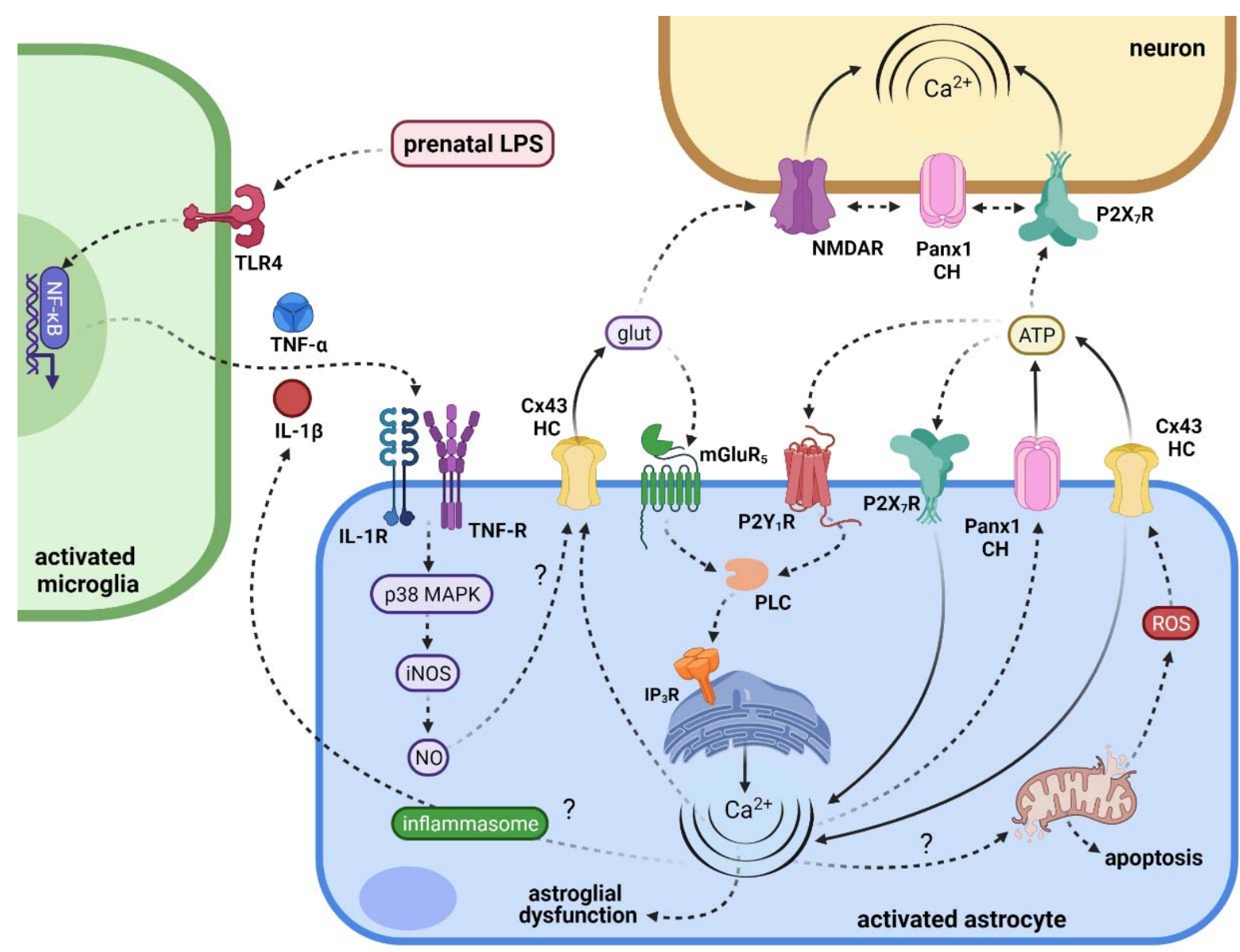

Figure 4. Diagram depicting the possible mechanisms and consequences of prenatal LPS-induced activation of Cx43 hemichannels/Panx1 channels in astrocytes. Indirectly, LPS exposure during pregnancy activates fetal and/or postnatal microglia, resulting in the TLR4 and NF-KB-dependent release of IL-1 $\beta$ and TNF- $\alpha$. These cytokines, acting on their respective receptors, stimulate the $\mathrm{p} 38 \mathrm{MAPK} / \mathrm{iNOS}$-dependent production of NO. The latter, possibly via de S-nitrosylation of $\mathrm{Cx} 43$, elicits the opening of $\mathrm{Cx} 43$ hemichannels and the subsequent release of glutamate and ATP through them. At one end, glutamate activates astrocyte mGluR5 receptors, causing the PLC-mediated stimulation of $\mathrm{IP}_{3}$ receptors and further release of $\mathrm{Ca}^{2+}$ stored in the endoplasmic reticulum. Meanwhile, ATP activates astrocyte $\mathrm{P} 2 \mathrm{X}_{7} \mathrm{Rs}$ and $\mathrm{P} 2 \mathrm{Y}_{1}$ Rs, triggering the opening of Panx1 channels by increasing $\left[\mathrm{Ca}^{2+}\right]_{\mathrm{i}}$ and/or direct protein-protein interaction with $\mathrm{P} 2 \mathrm{X}_{7} \mathrm{Rs}$. Of note, alterations in $\left[\mathrm{Ca}^{2+}\right]_{\mathrm{i}}$ homeostasis mediated by $\mathrm{C} \times 43$ hemichannel or Panx1 channels might affect diverse aspects of astroglial function (e.g., morphology and pro-inflammatory profile). Cytosolic $\mathrm{Ca}^{2+}$ might trigger the collapse of mitochondrial membrane potential, causing oxidative stress (a well-known $\mathrm{Cx} 43$ hemichannel activator) and apoptosis via cytochrome $\mathrm{C}$ release through the mitochondrial transition pore and activation of caspase-3. Another possibility is that cytosolic $\mathrm{Ca}^{2+}$ could potentiate the release of pro-inflammatory cytokines (e.g., IL-1 $\beta$ ) via the activation of the inflammasome. On the other hand, the excitotoxic release of glutamate and/or ATP through these channels could negatively impact neuronal $\left[\mathrm{Ca}^{2+}\right]_{\mathrm{i}}$ homeostasis and survival due to the activation of neuronal NMDARs, P2X $X_{7}$ Rs, and Panx1 channels. Solid lines depict fluxes of molecules through channels, whereas dashed lines indicate activation or induction. 
Given that NO reduces the opening of Panx1 channels either by S-nitrosylation [179] or PKG-dependent phosphorylation [180], their activation evoked by prenatal LPS possibly materialize due to alternative mechanisms. A significant component in opening Panx1 channels arises from ATP signaling and subsequent activation of purinergic receptors [181]. Panx1 co-immunoprecipitates with $\mathrm{P} 2 \mathrm{X}_{7}$ receptors $\left(\mathrm{P} 2 \mathrm{X}_{7} \mathrm{Rs}\right)[182,183]$ and seems to establish protein-to-protein interactions with them through the proline 451 in the C-terminal tail of P2X $X_{7} \mathrm{R}[184,185]$. Interestingly, prenatal LPS exposure induces the release of ATP from astrocytes in vitro and ex vivo by a mechanism involving the activation of both Panx1 channels and P2X $X_{7}$ receptors [170,174] (Figure 4). This result is consistent with other findings showing that ATP induces its release through a positive loop that implicates the opening of Panx 1 channels and subsequent activation of P2X $X_{7}$ Rs [117,141]. As in the case of IL-1 $\beta$ and TNF- $\alpha$, both microglia and/or astrocytes could act as sources for ATP signaling in the prenatally LPS-exposed adult offspring, thereby activating distant glial cells via P2X $X_{7}$ Rs. If so, the activation of $P 2 X_{7}$ Rs switches off due to the decrease of ATP by its diffusion to distant interstitial areas as its degradation by extracellular exonucleases. Alternatively, ATP could impede its release by directly blocking Panx1 channels [186]. Intriguingly, prenatal LPS enhances the expression of NLRP3 inflammasome and levels of IL-1 $\beta$ [187], while $P 2 X_{7}$ R-mediated opening of Panx 1 channels causes IL- $1 \beta$ secretion via activation of the inflammasome in different cell types, including astrocytes [182,188-191]. Whether or not the inflammasome contributes to the opening of astrocyte Panx1 channels following maternal LPS exposure has not been clarified and requires further study.

Is it $\mathrm{Ca}^{2+}$ signaling involved in prenatal LPS-induced hemichannel/pannexon opening in astrocytes? Both Cx43 hemichannels and Panx1 channels augment their activity upon a moderate rise in $\left[\mathrm{Ca}^{2+}\right]_{i}[147,159,192,193]$. Of note, astrocytes from prenatally LPSexposed offspring display increased spontaneous $\left[\mathrm{Ca}^{2+}\right]_{i}$ oscillations with large amplitude, which was found decisive for the activation of Cx43 hemichannels in these cells $[170,174]$ (Figure 4). More critical, this response causes the Cx43 hemichannel-dependent release of glutamate and subsequent rise of basal $\left[\mathrm{Ca}^{2+}\right]_{i}$ via intracellular stores, a response being underpinned by activation of metabotropic glutamate receptor subtype 5 (mGluR5) and further downstream action of PLC and $\mathrm{IP}_{3}$ receptors [174]. These findings harmonize with the increased release of glutamate observed in the hippocampus of prenatally LPS-exposed offspring [194] and with the fact that mGluR5 controls $\left[\mathrm{Ca}^{2+}\right]_{\mathrm{i}}$ responses in astrocytes [195].

\section{Repercussions of Hemichannel and Pannexon Activation in the Offspring Brain following Maternal Inflammation}

During pathological conditions, long-lasting activation of hemichannels and pannexons alters multiple aspects of astroglial function such as $\left[\mathrm{Ca}^{2+}\right]_{i}$ homeostasis, gliotransmission, inflammasome activation, cytokine secretion, redox potential, mitochondrial dynamics and survival [114,119-121,163,191,196-198]. How might these channels contribute to maternal LPS-induced astroglial dysfunction in the offspring? The inflammatory profile and homeostatic function of astrocytes require a delicate regulation of diverse $\left[\mathrm{Ca}^{2+}\right]_{\mathrm{i}}$ parameters, such as frequency, amplitude, the half-life of $\mathrm{Ca}^{2+}$ transient events, and relaxation states $[60,75,199]$. Because hemichannels and pannexons, directly or indirectly, cause the influx of $\mathrm{Ca}^{2+}[157,158,200-202]$ and their opening is modulated by $\left[\mathrm{Ca}^{2+}\right]_{\mathrm{i}}[147,159,192,193]$, they could significantly impact the function, reactivity, and fate of astrocytes. Supporting this line of thought, in vivo postnatal administration of TAT-gap19, a specific Cx43 hemichannel blocker that crosses the blood-brain barrier [203], prevents the prenatal LPS-evoked branch arborization and hypertrophy exhibited by adult hippocampal astrocytes [174], a well-recognized feature of reactive astrogliosis [82]. Similarly, the rise in GFAP expression observed in the hippocampus of prenatally-LPS exposed adult offspring was suppressed by the administration of TAT-gap19 [174]. These findings are consistent with other studies demonstrating that TAT-gap19 decreases reactive astrogliosis and microgliosis, as well as inflammatory cytokine levels in models of intracerebral hemorrhage injury and midbrain dopamine neurodegeneration [168,204]. Of note, specific blockade of Cx43 hemichannels augments the Yes-associated protein nuclear translocation, resulting 
in subsequent inhibition of TLR4-NFKB and JAK2-STAT3 pathways [168], the latter being crucial reactive astrogliosis [82].

Although it is unknown whether maternal inflammation affects the survival of astrocytes, the potential impact of hemichannels/pannexons in this phenomenon deserves analysis and might occur through different mechanisms. The hemichannel/pannexonmediated $\left[\mathrm{Ca}^{2+}\right]_{\mathrm{i}}$ overload could produce free radicals, lipid peroxidation, and plasma membrane damage [205]. Cytosolic $\mathrm{Ca}^{2+}$ might also translocate into the mitochondrial matrix, where it triggers the collapse of mitochondrial membrane potential, causing not only loss of ATP production and generation of reactive oxygen species (ROS) but also cell death via the release of cytochrome $\mathrm{C}$ through the mitochondrial transition pore and activation of caspase-3 [206,207]. In addition, multiple lines of work indicate that osmotic and ionic imbalances evoked by the increased influx of $\mathrm{Na}^{+}$and $\mathrm{Cl}^{-}$via hemichannels or pannexons could lead to subsequent cell swelling and plasma membrane breakdown [121,126,156,208]. Ultimately, as mentioned before, ATP released through Panx1 channels could be pivotal for the activation of the inflammasome, resulting in the secretion of mature IL- $1 \beta$ and IL-18, and the induction of pyroptosis, a lytic cell death accompanied by rapid cell-membrane rupture $[188,191,209,210]$. How could the transient activation of hemichannels/pannexons have a long-lasting effect on astroglial function? A possible explanation could be based on the hemichannel/pannexon-mediated $\left[\mathrm{Ca}^{2+}\right]_{\mathrm{i}}$ imbalance and subsequent activation of astrocytes. $\mathrm{Ca}^{2+}$ is known to regulate the function of diverse transcription factor pathways [211]; most of them (e.g., NFKB, JAK/STAT, FOX proteins, peroxisome proliferator-activated receptors, and activator protein-1) have been involved in sculpting gene-expression programs implicated in astrocyte activation [212]. With this in mind, once astrocytic $\left[\mathrm{Ca}^{2+}\right]_{\mathrm{i}}$ imbalance occurs after the activation of hemichannels/pannexons, there are various pathways through which cytosolic $\mathrm{Ca}^{2+}$ could sustain the reactive phenotype of astrocytes.

Maternal inflammation impairs hippocampal-mediated cognitive behavior $[21,22,24,28]$ and long-term potentiation [213]. Both phenomena associate with dendritic retraction of pyramidal neurons and loss of synapses in diverse neurological conditions [214,215], including maternal LPS exposure [216]. Notably, blockade of Cx43 hemichannels with TAT-gap19 completely prevents the prenatal LPS-induced reduction of hippocampal neurite arborization and length, as well as the decline in dendritic spine density [174]. Most significantly, the increased death of CA1 pyramidal neurons observed in offspring hippocampus was completely prevented by inhibiting Cx43 hemichannels in this pathological model. This evidence indicates that by altering the functions of astrocytes and/or releasing excitotoxic amounts of gliotransmitters, Cx43 hemichannels would be crucial protagonists in neuronal damage and synaptic dysfunction induced by maternal inflammation. The latter idea is strengthened in light of other antecedents showing that LPS-induced impairment of excitatory synaptic activity depends on the opening of astroglial Cx43 hemichannels [114].

How might prenatal LPS-induced opening of astrocytic hemichannels and pannexons impair neuronal function and survival? At one end, it is plausible to hypothesize that $\left[\mathrm{Ca}^{2+}\right]_{\mathrm{i}}$ imbalance linked to the opening of astrocytic hemichannels and pannexons could disturb essential functions that sustain not only astrocytic survival but also astrocyte-toneuron support, including energy and redox homeostasis, uptake of $\mathrm{K}^{+}$and glutamate, and the delivery of neurotrophic factors and energy-rich metabolites. Both phenomena, either the dysfunction of astrocytes or a reduction in their number triggered by maternal inflammation, could make neurons more susceptible to the deleterious effect of prenatal LPS exposure itself and/or the experience of a second immune challenge during adulthood (see the "two-hit" explanation for the schizophrenia etiology [217]). At the other end, it is possible to conjecture that prenatal LPS exposure could cause excitotoxicity by producing the release of high amounts of gliotransmitters via hemichannels/pannexons, eliciting further neuronal damage. In agreement with the latter idea, prenatal LPS exposure prompts the Cx43 hemichannel/Panx1 channel-dependent release of glutamate and ATP from astrocytes, making neurons in cultures or brain slices toxic [170,174] (Figure 5). Even more 
critical, the use of astroglial conditioned media revealed that ATP and further activation of neuronal Panx1 channels contribute to neuronal loss caused by prenatal LPS exposure [170].

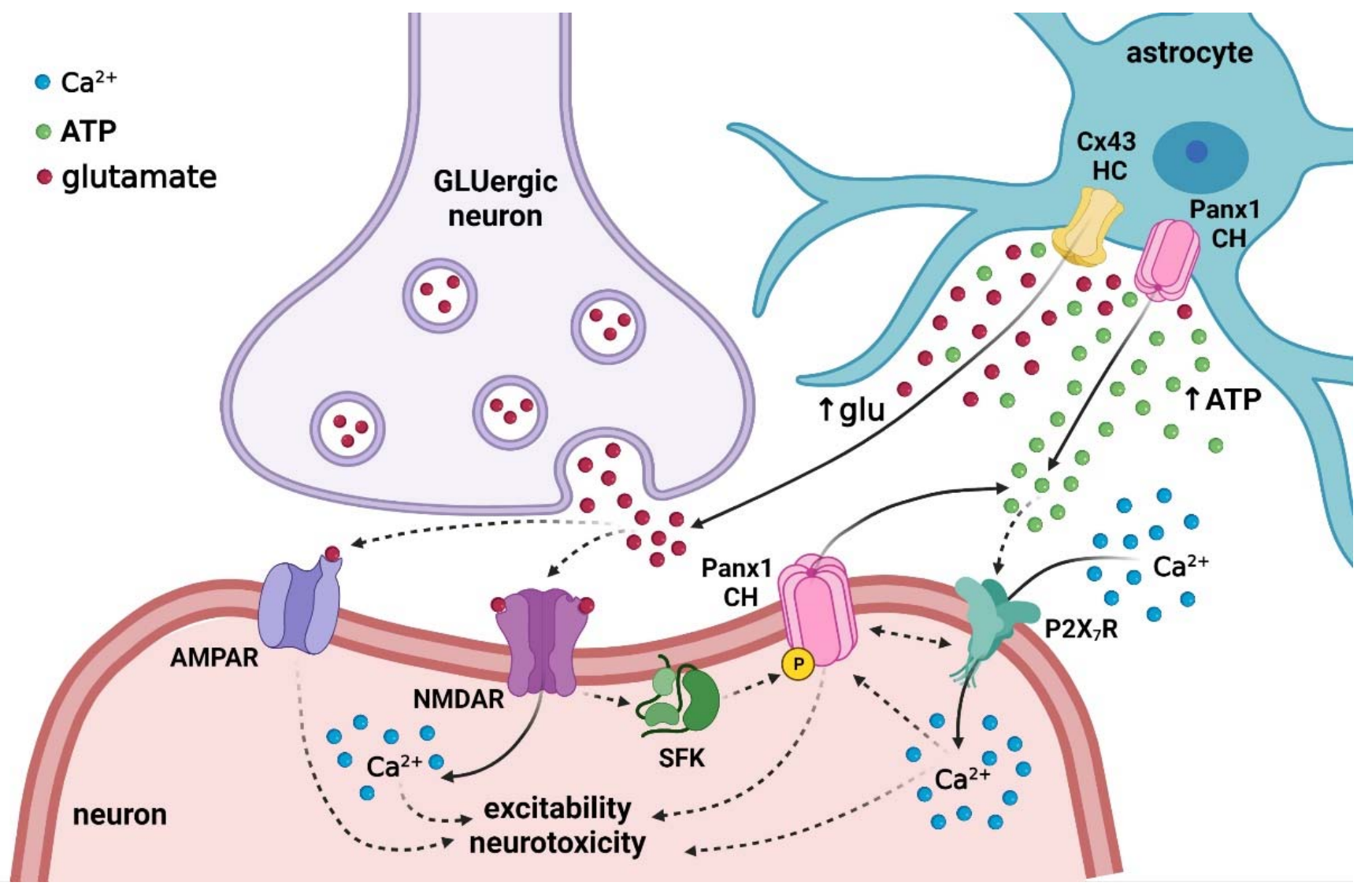

Figure 5. Possible detrimental roles on synaptic transmission of astroglial Cx43 hemichannels and Panx1 channels in prenatally LPS-exposed offspring. Prenatal LPS exposure raises postnatal cytokine brain levels, causing the opening of Cx43 hemichannels and Panx1 channels in astrocytes. The latter underpins the release of astrocytic ATP and glutamate towards the synaptic cleft. ATP could stimulate $\mathrm{P} 2 \mathrm{X}_{7} \mathrm{Rs}$, whereas glutamate might activate NMDARs and AMPARs in postsynaptic terminals of glutamatergic circuits. The downstream signaling of these receptors triggers the increase of $\left[\mathrm{Ca}^{2+}\right]_{\mathrm{i}}$, a phenomenon that the activation of neuronal Panx1 channels could exacerbate. This responsecould occur at least by two mechanisms: (i) via protein-protein interactions between Panx1 and P2 $X_{7}$ Rs or (ii) due to the phosphorylation of Panx1 as a result of Src kinase (SFK) action mediated by the metabotropic function of NMDARs. The persistent activation of hemichannels/pannexons at the synaptic cleft might create a self-perpetuating loop of $\left[\mathrm{Ca}^{2+}\right]_{i}$ imbalance with substantial and detrimental consequences for proper synaptic transmission and neuronal survival. Solid lines depict fluxes of molecules through channels, whereas dashed lines indicate activation or induction.

Neurons express functional Panx1 channels [218,219], whereas their ability to constitute connexons or hemichannels is still a matter of investigation [220,221]. In other systems, it has been proposed that ATP could trigger the opening of neuronal Panx1 channels via the above-mentioned protein-protein interactions between these channels and P2X $\mathrm{X}_{7} \mathrm{Rs}$ or via stimulation of P2Y receptors and further raising of $\left[\mathrm{Ca}^{2+}\right]_{i}[111,112]$. In the case of maternal inflammation, it seems that $\mathrm{P} 2 \mathrm{X}_{7}$ Rs rather than $\mathrm{P}_{2} \mathrm{Y}_{1}$ Rs contribute to the astroglial ATP-mediated neuronal death in prenatally LPS-exposed offspring [170] (Figure 5). Alternatively, Panx1 channels could be opened by a rise in $\left[\mathrm{Ca}^{2+}\right]_{i}$ and further phosphorylation of the Panx1 amino acid residue S394 by activated CaMKII, as recently demonstrated in cells subjected to membrane stretch [193]. Although glutamate released via astroglial Cx43 hemichannels increases levels of astroglial basal $\left[\mathrm{Ca}^{2+}\right]_{\mathrm{i}}$ following maternal inflammation [174], it remains unknown whether this gliotransmitter influences neuronal survival. 
If so, the activation of neuronal Panx1 channels might arise as a possible mechanism in the downstream signaling of glutamate-induced neuronal loss linked to $N$-methyl-D-aspartate receptors (NMDARs) and Src family kinase (SFK) [222]. In this multiprotein complex, the metabotropic activation of NMDARs recruits SFK to open Panx1 channels via phosphorylation of Panx1 C-terminus, producing sustained neuronal depolarizations and consequent excitotoxicity during anoxia/ischemia [222-224].

\section{Conclusions}

The CNS needs protection from endogenous and exogenous threats. The notion of the brain being a privileged organ with a poor immune capacity does not conciliate with recent evidence indicating that it performs complex immune responses primarily based on its innate immune system, a "first line" of defense ensuring brain homeostasis [225-227]. Along with microglia, astrocytes are cornerstones in this process as they restrain infection and eliminate pathogens, cell debris, and misfolded proteins. Astrocytes also sense neuronal activity and respond locally to it through the release of gliotransmitters that further modulate synaptic function and transmission. The findings discussed in this review support the idea that activation of astrocyte $\mathrm{Cx} 43$ hemichannels and Panx1 channels could contribute to offspring brain abnormalities observed following maternal inflammation. In particular, the opening of these channels could be the hidden link between brain innate immune activation occurring at early phases of fetal development and postnatal decline in synaptic function and transmission. Further studies will clarify whether astroglial hemichannel/pannexon opening evoked by prenatal inflammation takes place just at postnatal stages or during fetal development as well.

An aspect that remains puzzling is whether maternal inflammation activates astroglial hemichannels/pannexons in manners that differ in intensity and temporal kinetics depending on the nature of the immune stimuli (e.g., viruses, bacteria, and protozoa). In such a case, the outcomes in synaptic function and neuronal survival could be considerably different. It seems clear that prenatal inflammation plays a central role in opening these channels as it occurs following other maternal stressors not necessarily linked to infections. For instance, the combination of prenatal nicotine exposure and postnatal high-fat/cholesterol diet produces the activation of hemichannels/pannexons in astrocytes, microglia, and neurons, a response associated with cytokine production that does not occur when animals are exposed to these stressors separately [228]. In the same direction, maternal exposure to high doses of dexamethasone activates the NLRP3 inflammasome, which results in the opening of oligodendrocyte hemichannels in a P2 $X_{7} \mathrm{R}$-dependent manner [229]. Understanding how hemichannels and pannexons participate in the impairment of astrocyte-neuron crosstalk during and after maternal inflammation could be critical for developing pharmacological therapies against neurological disorders observed in the offspring.

Author Contributions: Conceptualization, J.P.-V., T.F.A., A.L., C.M.L., C.J.M.-A., J.B., C.A.I., G.R., G.I.G., J.A.O.; Writing - Original Draft Preparation, J.A.O.; Writing-Review and Editing, J.P.-V., T.F.A., A.L., C.M.L., C.J.M.-A., J.B., C.A.I., G.R., G.I.G., J.A.O.; Visualization, J.P.-V., T.F.A., A.L., C.M.L., C.J.M.-A., J.B., C.A.I., G.R., G.I.G., J.A.O. (Figures were created with BioRender.com); Supervision, J.A.O.; Project Administration, J.A.O.; Funding Acquisition, G.I.G. and J.A.O. All authors have read and agreed to the published version of the manuscript.

Funding: This research was funded by the Agencia Nacional de Investigación y Desarrollo (ANID), Fondo Nacional de Desarrollo Científico y Tecnológico (FONDECYT) Grant 1210375 (to JAO), Grant 11200584 (to GIG).

Conflicts of Interest: All authors have read and agreed to the published version of the manuscript. 


$\begin{array}{ll}\text { Abbreviations } \\ \text { ASD } & \text { autism spectrum disorder } \\ \text { CNS } & \text { Central nervous system } \\ \text { COVID-19 } & \text { coronavirus disease } 2019 \\ \text { Cx43 } & \text { Connexin } 43 \\ \text { Etd } & \text { Ethidium } \\ \text { GFAP } & \text { glial fibrillary acidic protein } \\ \text { IL-1 } \beta & \text { Interleukin-1 } \beta \\ \text { iNOS } & \text { inducible NO synthase } \\ {\left[\text { Ca }{ }^{2+}\right]_{i}} & \text { Intracellular Ca }{ }^{2+} \\ \text { LPS } & \text { lipopolysaccharide } \\ \text { NAD } & \text { Nicotinamide adenine dinucleotide } \\ \text { NMDAR } & \text { N-methyl-D-aspartate receptor } \\ \text { NO } & \text { nitric oxide } \\ \text { Panx1 PGE } 2 & \text { Pannexin-1 Prostaglandin E } \\ \text { Poly (I:C) } & \text { polyriboinosinic-polyribocytidilic acid } \\ \text { P2X } \text { Rs }^{+} & \text {P2X }{ }_{7} \text { receptors } \\ \text { p38 MAPK } & \text { p38 mitogen-activated protein kinase } \\ \text { ROS } & \text { reactive oxygen species } \\ \text { SFK } & \text { Src family kinase } \\ \text { IFNs } & \text { type I interferons } \\ \text { TNF- } \alpha & \text { Tumor necrosis factor- } \alpha\end{array}$

\section{References}

1. Burton, G.J.; Fowden, A.L.; Thornburg, K.L. Placental Origins of Chronic Disease. Physiol. Rev. 2016, 96, 1509-1565. [CrossRef] [PubMed]

2. Prudhomme, J.; Morey, C. Epigenesis and plasticity of mouse trophoblast stem cells. Cell Mol. Life Sci. 2016, 73, 757-774. [CrossRef] [PubMed]

3. Padmanabhan, V.; Cardoso, R.C.; Puttabyatappa, M. Developmental Programming, a Pathway to Disease. Endocrinology 2016, 157, 1328-1340. [CrossRef] [PubMed]

4. Meyer, U. Neurodevelopmental Resilience and Susceptibility to Maternal Immune Activation. Trends Neurosci. 2019, 42, 793-806. [CrossRef] [PubMed]

5. Gumusoglu, S.B.; Stevens, H.E. Maternal Inflammation and Neurodevelopmental Programming: A Review of Preclinical Outcomes and Implications for Translational Psychiatry. Biol. Psychiatry 2019, 85, 107-121. [CrossRef] [PubMed]

6. Torrey, E.F.; Peterson, M.R. Slow and latent viruses in schizophrenia. Lancet 1973, 2, 22-24. [CrossRef]

7. Menninger, K.A. Psychoses Associated with Influenza I. General Data: Statistical Analysis. J. Am. Med. Assoc. 1919, 72, $235-241$. [CrossRef]

8. Mednick, S.A.; Machon, R.A.; Huttunen, M.O.; Bonett, D. Adult schizophrenia following prenatal exposure to an influenza epidemic. Arch. Gen. Psychiatry 1988, 45, 189-192. [CrossRef]

9. Brown, A.S.; Derkits, E.J. Prenatal infection and schizophrenia: A review of epidemiologic and translational studies. Am. J. Psychiatry 2010, 167, 261-280. [CrossRef]

10. Choudhury, Z.; Lennox, B. Maternal Immune Activation and Schizophrenia-Evidence for an Immune Priming Disorder. Front. Psychiatry 2021, 12, 585742. [CrossRef]

11. Chess, S. Follow-up report on autism in congenital rubella. J. Autism Child. Schizophr. 1977, 7, 69-81. [CrossRef]

12. Libbey, J.E.; Sweeten, T.L.; McMahon, W.M.; Fujinami, R.S. Autistic disorder and viral infections. J. Neurovirol. 2005, 11, 1-10. [CrossRef]

13. Murphy, D.J.; Sellers, S.; MacKenzie, I.Z.; Yudkin, P.L.; Johnson, A.M. Case-control study of antenatal and intrapartum risk factors for cerebral palsy in very preterm singleton babies. Lancet 1995, 346, 1449-1454. [CrossRef]

14. Clark, S.M.; Ghulmiyyah, L.M.; Hankins, G.D. Antenatal antecedents and the impact of obstetric care in the etiology of cerebral palsy. Clin. Obstet. Gynecol. 2008, 51, 775-786. [CrossRef] [PubMed]

15. Camp, B.W.; Broman, S.H.; Nichols, P.L.; Leff, M. Maternal and neonatal risk factors for mental retardation: Defining the 'at-risk' child. Early Hum. Dev. 1998, 50, 159-173. [CrossRef]

16. Hamdani, N.; Daban-Huard, C.; Lajnef, M.; Richard, J.R.; Delavest, M.; Godin, O.; Le Guen, E.; Vederine, F.E.; Lepine, J.P.; Jamain, S.; et al. Relationship between Toxoplasma gondii infection and bipolar disorder in a French sample. J. Affect. Disord. 2013, 148, 444-448. [CrossRef]

17. Zimmer, A.; Youngblood, A.; Adnane, A.; Miller, B.J.; Goldsmith, D.R. Prenatal exposure to viral infection and neuropsychiatric disorders in offspring: A review of the literature and recommendations for the COVID-19 pandemic. Brain Behav. Immun. 2021, 91, 756-770. [CrossRef] 
18. Boksa, P. Effects of prenatal infection on brain development and behavior: A review of findings from animal models. Brain Behav. Immun. 2010, 24, 881-897. [CrossRef]

19. Rathinam, V.A.K.; Zhao, Y.; Shao, F. Innate immunity to intracellular LPS. Nat. Immunol. 2019, 20, 527-533. [CrossRef]

20. Kimura, M.; Toth, L.A.; Agostini, H.; Cady, A.B.; Majde, J.A.; Krueger, J.M. Comparison of acute phase responses induced in rabbits by lipopolysaccharide and double-stranded RNA. Am. J. Physiol. 1994, 267, R1596-R1605. [CrossRef] [PubMed]

21. Meyer, U.; Nyffeler, M.; Engler, A.; Urwyler, A.; Schedlowski, M.; Knuesel, I.; Yee, B.K.; Feldon, J. The time of prenatal immune challenge determines the specificity of inflammation-mediated brain and behavioral pathology. J. Neurosci. Off. J. Soc. Neurosci. 2006, 26, 4752-4762. [CrossRef]

22. Meyer, U.; Murray, P.J.; Urwyler, A.; Yee, B.K.; Schedlowski, M.; Feldon, J. Adult behavioral and pharmacological dysfunctions following disruption of the fetal brain balance between pro-inflammatory and IL-10-mediated anti-inflammatory signaling. Mol. Psychiatry 2008, 13, 208-221. [CrossRef] [PubMed]

23. Golan, H.M.; Lev, V.; Hallak, M.; Sorokin, Y.; Huleihel, M. Specific neurodevelopmental damage in mice offspring following maternal inflammation during pregnancy. Neuropharmacology 2005, 48, 903-917. [CrossRef]

24. Stolp, H.B.; Turnquist, C.; Dziegielewska, K.M.; Saunders, N.R.; Anthony, D.C.; Molnar, Z. Reduced ventricular proliferation in the foetal cortex following maternal inflammation in the mouse. Brain J. Neurol. 2011, 134, 3236-3248. [CrossRef] [PubMed]

25. Andoh, M.; Shibata, K.; Okamoto, K.; Onodera, J.; Morishita, K.; Miura, Y.; Ikegaya, Y.; Koyama, R. Exercise Reverses Behavioral and Synaptic Abnormalities after Maternal Inflammation. Cell Rep. 2019, 27, 2817-2825.e5. [CrossRef] [PubMed]

26. Meyer, U. Prenatal poly(i:C) exposure and other developmental immune activation models in rodent systems. Biol. Psychiatry 2014, 75, 307-315. [CrossRef]

27. Meyer, U.; Feldon, J.; Schedlowski, M.; Yee, B.K. Towards an immuno-precipitated neurodevelopmental animal model of schizophrenia. Neurosci. Biobehav. Rev. 2005, 29, 913-947. [CrossRef] [PubMed]

28. Golan, H.; Stilman, M.; Lev, V.; Huleihel, M. Normal aging of offspring mice of mothers with induced inflammation during pregnancy. Neuroscience 2006, 141, 1909-1918. [CrossRef]

29. Girard, S.; Kadhim, H.; Beaudet, N.; Sarret, P.; Sebire, G. Developmental motor deficits induced by combined fetal exposure to lipopolysaccharide and early neonatal hypoxia/ischemia: A novel animal model for cerebral palsy in very premature infants. Neuroscience 2009, 158, 673-682. [CrossRef]

30. Gilmore, J.H.; Jarskog, L.F. Exposure to infection and brain development: Cytokines in the pathogenesis of schizophrenia. Schizophr. Res. 1997, 24, 365-367. [CrossRef]

31. Saliba, E.; Henrot, A. Inflammatory mediators and neonatal brain damage. Biol. Neonate 2001, 79, 224-227. [PubMed]

32. Jones, K.L.; Croen, L.A.; Yoshida, C.K.; Heuer, L.; Hansen, R.; Zerbo, O.; DeLorenze, G.N.; Kharrazi, M.; Yolken, R.; Ashwood, P.; et al. Autism with intellectual disability is associated with increased levels of maternal cytokines and chemokines during gestation. Mol. Psychiatry 2017, 22, 273-279. [CrossRef]

33. Mac Giollabhui, N.; Breen, E.C.; Murphy, S.K.; Maxwell, S.D.; Cohn, B.A.; Krigbaum, N.Y.; Cirillo, P.M.; Perez, C.; Alloy, L.B.; Drabick, D.A.G.; et al. Maternal inflammation during pregnancy and offspring psychiatric symptoms in childhood: Timing and sex matter. J. Psychiatr. Res. 2019, 111, 96-103. [CrossRef] [PubMed]

34. Brown, A.S.; Meyer, U. Maternal Immune Activation and Neuropsychiatric Illness: A Translational Research Perspective. Am. J. Psychiatry 2018, 175, 1073-1083. [CrossRef]

35. Girard, S.; Tremblay, L.; Lepage, M.; Sebire, G. IL-1 receptor antagonist protects against placental and neurodevelopmental defects induced by maternal inflammation. J. Immunol. 2010, 184, 3997-4005. [CrossRef] [PubMed]

36. Choi, G.B.; Yim, Y.S.; Wong, H.; Kim, S.; Kim, H.; Kim, S.V.; Hoeffer, C.A.; Littman, D.R.; Huh, J.R. The maternal interleukin-17a pathway in mice promotes autism-like phenotypes in offspring. Science 2016, 351, 933-939. [CrossRef]

37. Smith, S.E.; Li, J.; Garbett, K.; Mirnics, K.; Patterson, P.H. Maternal immune activation alters fetal brain development through interleukin-6. J. Neurosci. Off. J. Soc. Neurosci. 2007, 27, 10695-10702. [CrossRef]

38. Nilsen, N.; Nonstad, U.; Khan, N.; Knetter, C.F.; Akira, S.; Sundan, A.; Espevik, T.; Lien, E. Lipopolysaccharide and doublestranded RNA up-regulate toll-like receptor 2 independently of myeloid differentiation factor 88. J. Biol. Chem. 2004, 279, 39727-39735. [CrossRef] [PubMed]

39. Gromkowski, S.H.; Mama, K.; Yagi, J.; Sen, R.; Rath, S. Double-stranded RNA and bacterial lipopolysaccharide enhance sensitivity to TNF-alpha-mediated cell death. Int. Immunol. 1990, 2, 903-908. [CrossRef] [PubMed]

40. Hemmi, H.; Takeuchi, O.; Sato, S.; Yamamoto, M.; Kaisho, T.; Sanjo, H.; Kawai, T.; Hoshino, K.; Takeda, K.; Akira, S. The roles of two IkappaB kinase-related kinases in lipopolysaccharide and double stranded RNA signaling and viral infection. J. Exp. Med. 2004, 199, 1641-1650. [CrossRef]

41. Reimer, T.; Brcic, M.; Schweizer, M.; Jungi, T.W. poly(I:C) and LPS induce distinct IRF3 and NF-kappaB signaling during type-I IFN and TNF responses in human macrophages. J. Leukoc. Biol. 2008, 83, 1249-1257. [CrossRef]

42. Hopwood, N.; Maswanganyi, T.; Harden, L.M. Comparison of anorexia, lethargy, and fever induced by bacterial and viral mimetics in rats. Can. J. Physiol. Pharm. 2009, 87, 211-220. [CrossRef]

43. Goldstein, J.A.; Gallagher, K.; Beck, C.; Kumar, R.; Gernand, A.D. Maternal-Fetal Inflammation in the Placenta and the Developmental Origins of Health and Disease. Front. Immunol. 2020, 11, 531543. [CrossRef]

44. Rosenfeld, C.S. The placenta-brain-axis. J. Neurosci. Res. 2021, 99, 271-283. [CrossRef] 
45. Wright-Jin, E.C.; Gutmann, D.H. Microglia as Dynamic Cellular Mediators of Brain Function. Trends Mol. Med. 2019, 25, 967-979. [CrossRef]

46. Zhang, Z.; Bassam, B.; Thomas, A.G.; Williams, M.; Liu, J.; Nance, E.; Rojas, C.; Slusher, B.S.; Kannan, S. Maternal inflammation leads to impaired glutamate homeostasis and up-regulation of glutamate carboxypeptidase II in activated microglia in the fetal/newborn rabbit brain. Neurobiol. Dis. 2016, 94, 116-128. [CrossRef] [PubMed]

47. Ozaki, K.; Kato, D.; Ikegami, A.; Hashimoto, A.; Sugio, S.; Guo, Z.; Shibushita, M.; Tatematsu, T.; Haruwaka, K.; Moorhouse, A.J.; et al. Maternal immune activation induces sustained changes in fetal microglia motility. Sci. Rep. 2020, 10, 21378. [CrossRef]

48. Schaafsma, W.; Basterra, L.B.; Jacobs, S.; Brouwer, N.; Meerlo, P.; Schaafsma, A.; Boddeke, E.; Eggen, B.J.L. Maternal inflammation induces immune activation of fetal microglia and leads to disrupted microglia immune responses, behavior, and learning performance in adulthood. Neurobiol. Dis. 2017, 106, 291-300. [CrossRef] [PubMed]

49. Antonson, A.M.; Lawson, M.A.; Caputo, M.P.; Matt, S.M.; Leyshon, B.J.; Johnson, R.W. Maternal viral infection causes global alterations in porcine fetal microglia. Proc. Natl. Acad. Sci. USA 2019, 116, 20190-20200. [CrossRef] [PubMed]

50. Delpech, J.C.; Wei, L.; Hao, J.; Yu, X.; Madore, C.; Butovsky, O.; Kaffman, A. Early life stress perturbs the maturation of microglia in the developing hippocampus. Brain Behav. Immun. 2016, 57, 79-93. [CrossRef]

51. Abbink, M.R.; van Deijk, A.F.; Heine, V.M.; Verheijen, M.H.; Korosi, A. The involvement of astrocytes in early-life adversity induced programming of the brain. Glia 2019, 67, 1637-1653. [CrossRef] [PubMed]

52. Snyder-Keller, A.; Stark, P.F. Prenatal inflammatory effects on nigrostriatal development in organotypic cultures. Brain Res. 2008, 1233, 160-167. [CrossRef] [PubMed]

53. Samuelsson, A.M.; Jennische, E.; Hansson, H.A.; Holmang, A. Prenatal exposure to interleukin-6 results in inflammatory neurodegeneration in hippocampus with NMDA/GABA(A) dysregulation and impaired spatial learning. Am. J. Physiol. Regul. Integr. Comp. Physiol. 2006, 290, R1345-R1356. [CrossRef] [PubMed]

54. Van Tilborg, E.; Heijnen, C.J.; Benders, M.J.; van Bel, F.; Fleiss, B.; Gressens, P.; Nijboer, C.H. Impaired oligodendrocyte maturation in preterm infants: Potential therapeutic targets. Prog. Neurobiol. 2016, 136, 28-49. [CrossRef] [PubMed]

55. Ito, T.; Hoshiai, K.; Tanabe, K.; Nakamura, A.; Funamoto, K.; Aoyagi, A.; Chisaka, H.; Okamura, K.; Yaegashi, N.; Kimura, Y. Maternal undernutrition with vaginal inflammation impairs the neonatal oligodendrogenesis in mice. Tohoku J. Exp. Med. 2011, 223, 215-222. [CrossRef] [PubMed]

56. Verkhratsky, A.; Nedergaard, M. Physiology of Astroglia. Physiol. Rev. 2018, 98, 239-389. [CrossRef]

57. Cornell-Bell, A.H.; Finkbeiner, S.M.; Cooper, M.S.; Smith, S.J. Glutamate induces calcium waves in cultured astrocytes: Long-range glial signaling. Science 1990, 247, 470-473. [CrossRef] [PubMed]

58. Nedergaard, M. Direct signaling from astrocytes to neurons in cultures of mammalian brain cells. Science 1994, $263,1768-1771$. [CrossRef]

59. Parpura, V.; Basarsky, T.A.; Liu, F.; Jeftinija, K.; Jeftinija, S.; Haydon, P.G. Glutamate-mediated astrocyte-neuron signalling. Nature 1994, 369, 744-747. [CrossRef]

60. Rusakov, D.A. Disentangling calcium-driven astrocyte physiology. Nat. Rev. Neurosci. 2015, 16, 226-233. [CrossRef]

61. Bazargani, N.; Attwell, D. Astrocyte calcium signaling: The third wave. Nat. Neurosci. 2016, 19, 182-189. [CrossRef]

62. Perea, G.; Navarrete, M.; Araque, A. Tripartite synapses: Astrocytes process and control synaptic information. Trends Neurosci. 2009, 32, 421-431. [CrossRef]

63. Dallerac, G.; Zapata, J.; Rouach, N. Versatile control of synaptic circuits by astrocytes: Where, when and how? Nat. Rev. Neurosci. 2018, 19, 729-743. [CrossRef]

64. Allaman, I.; Belanger, M.; Magistretti, P.J. Astrocyte-neuron metabolic relationships: For better and for worse. Trends Neurosci. 2011, 34, 76-87. [CrossRef] [PubMed]

65. Iadecola, C.; Nedergaard, M. Glial regulation of the cerebral microvasculature. Nat. Neurosci. 2007, 10, 1369-1376. [CrossRef] [PubMed]

66. Mayorquin, L.C.; Rodriguez, A.V.; Sutachan, J.J.; Albarracin, S.L. Connexin-Mediated Functional and Metabolic Coupling Between Astrocytes and Neurons. Front. Mol. Neurosci. 2018, 11, 118. [CrossRef] [PubMed]

67. Pellerin, L.; Magistretti, P.J. Glutamate uptake into astrocytes stimulates aerobic glycolysis: A mechanism coupling neuronal activity to glucose utilization. Proc. Natl. Acad. Sci. USA 1994, 91, 10625-10629. [CrossRef]

68. Wyss, M.T.; Jolivet, R.; Buck, A.; Magistretti, P.J.; Weber, B. In vivo evidence for lactate as a neuronal energy source. J. Neurosci. Off. J. Soc. Neurosci. 2011, 31, 7477-7485. [CrossRef]

69. Bak, L.K.; Walls, A.B.; Schousboe, A.; Ring, A.; Sonnewald, U.; Waagepetersen, H.S. Neuronal glucose but not lactate utilization is positively correlated with NMDA-induced neurotransmission and fluctuations in cytosolic $\mathrm{Ca}^{2+}$ levels. J. Neurochem. 2009, 109 (Suppl. S1), 87-93. [CrossRef]

70. Weber, B.; Barros, L.F. The Astrocyte: Powerhouse and Recycling Center. Cold Spring Harb. Perspect. Biol. 2015, 7, a020396. [CrossRef]

71. Wang, X.; Michaelis, E.K. Selective neuronal vulnerability to oxidative stress in the brain. Front. Aging Neurosci. $2010,2,12$. [CrossRef] [PubMed]

72. Zhao, J.; Yu, S.; Zheng, Y.; Yang, H.; Zhang, J. Oxidative Modification and Its Implications for the Neurodegeneration of Parkinson's Disease. Mol. Neurobiol. 2017, 54, 1404-1418. [CrossRef] [PubMed] 
73. Bolanos, J.P. Bioenergetics and redox adaptations of astrocytes to neuronal activity. J. Neurochem. 2016, 139 (Suppl. S2), 115-125. [CrossRef] [PubMed]

74. Davis, C.H.; Kim, K.Y.; Bushong, E.A.; Mills, E.A.; Boassa, D.; Shih, T.; Kinebuchi, M.; Phan, S.; Zhou, Y.; Bihlmeyer, N.A.; et al. Transcellular degradation of axonal mitochondria. Proc. Natl. Acad. Sci. USA 2014, 111, 9633-9638. [CrossRef]

75. Jackson, J.G.; Robinson, M.B. Reciprocal Regulation of Mitochondrial Dynamics and Calcium Signaling in Astrocyte Processes. J. Neurosci. Off. J. Soc. Neurosci. 2015, 35, 15199-15213. [CrossRef]

76. Kirichok, Y.; Krapivinsky, G.; Clapham, D.E. The mitochondrial calcium uniporter is a highly selective ion channel. Nature 2004, 427, 360-364. [CrossRef]

77. Werth, J.L.; Thayer, S.A. Mitochondria buffer physiological calcium loads in cultured rat dorsal root ganglion neurons. J. Neurosci. Off. J. Soc. Neurosci. 1994, 14, 348-356. [CrossRef]

78. Bernardi, P.; Petronilli, V. The permeability transition pore as a mitochondrial calcium release channel: A critical appraisal. J. Bioenerg. Biomembr. 1996, 28, 131-138. [CrossRef]

79. Agarwal, A.; Wu, P.H.; Hughes, E.G.; Fukaya, M.; Tischfield, M.A.; Langseth, A.J.; Wirtz, D.; Bergles, D.E. Transient Opening of the Mitochondrial Permeability Transition Pore Induces Microdomain Calcium Transients in Astrocyte Processes. Neuron 2017, 93, 587-605. [CrossRef]

80. O'Donnell, J.C.; Jackson, J.G.; Robinson, M.B. Transient Oxygen/Glucose Deprivation Causes a Delayed Loss of Mitochondria and Increases Spontaneous Calcium Signaling in Astrocytic Processes. J. Neurosci. Off. J. Soc. Neurosci. 2016, 36, 7109-7127. [CrossRef]

81. Sofroniew, M.V. Molecular dissection of reactive astrogliosis and glial scar formation. Trends Neurosci. 2009, 32, 638-647. [CrossRef] [PubMed]

82. Pekny, M.; Pekna, M. Astrocyte reactivity and reactive astrogliosis: Costs and benefits. Physiol. Rev. 2014, 94, 1077-1098. [CrossRef]

83. Pekny, M.; Pekna, M.; Messing, A.; Steinhauser, C.; Lee, J.M.; Parpura, V.; Hol, E.M.; Sofroniew, M.V.; Verkhratsky, A. Astrocytes: A central element in neurological diseases. Acta Neuropathol. 2016, 131, 323-345. [CrossRef] [PubMed]

84. Volpe, J.J. Neurobiology of periventricular leukomalacia in the premature infant. Pediatr. Res. 2001, 50, 553-562. [CrossRef]

85. Folkerth, R.D.; Keefe, R.J.; Haynes, R.L.; Trachtenberg, F.L.; Volpe, J.J.; Kinney, H.C. Interferon-gamma expression in periventricular leukomalacia in the human brain. Brain Pathol. 2004, 14, 265-274. [CrossRef] [PubMed]

86. Haynes, R.L.; Folkerth, R.D.; Keefe, R.J.; Sung, I.; Swzeda, L.I.; Rosenberg, P.A.; Volpe, J.J.; Kinney, H.C. Nitrosative and oxidative injury to premyelinating oligodendrocytes in periventricular leukomalacia. J. Neuropathol. Exp. Neurol. 2003, 62, 441-450. [CrossRef]

87. Cai, Z.; Pan, Z.L.; Pang, Y.; Evans, O.B.; Rhodes, P.G. Cytokine induction in fetal rat brains and brain injury in neonatal rats after maternal lipopolysaccharide administration. Pediatr. Res. 2000, 47, 64-72. [CrossRef] [PubMed]

88. Rousset, C.I.; Chalon, S.; Cantagrel, S.; Bodard, S.; Andres, C.; Gressens, P.; Saliba, E. Maternal exposure to LPS induces hypomyelination in the internal capsule and programmed cell death in the deep gray matter in newborn rats. Pediatr. Res. 2006, 59, 428-433. [CrossRef]

89. Rousset, C.I.; Kassem, J.; Olivier, P.; Chalon, S.; Gressens, P.; Saliba, E. Antenatal bacterial endotoxin sensitizes the immature rat brain to postnatal excitotoxic injury. J. Neuropathol. Exp. Neurol. 2008, 67, 994-1000. [CrossRef]

90. Hao, L.Y.; Hao, X.Q.; Li, S.H.; Li, X.H. Prenatal exposure to lipopolysaccharide results in cognitive deficits in age-increasing offspring rats. Neuroscience 2010, 166, 763-770. [CrossRef] [PubMed]

91. O'Loughlin, E.; Pakan, J.M.P.; Yilmazer-Hanke, D.; McDermott, K.W. Acute in utero exposure to lipopolysaccharide induces inflammation in the pre- and postnatal brain and alters the glial cytoarchitecture in the developing amygdala. J. Neuroinflamm. 2017, 14, 212. [CrossRef] [PubMed]

92. Fatemi, S.H.; Emamian, E.S.; Sidwell, R.W.; Kist, D.A.; Stary, J.M.; Earle, J.A.; Thuras, P. Human influenza viral infection in utero alters glial fibrillary acidic protein immunoreactivity in the developing brains of neonatal mice. Mol. Psychiatry 2002, 7, 633-640. [CrossRef] [PubMed]

93. Ratnayake, U.; Quinn, T.A.; Castillo-Melendez, M.; Dickinson, H.; Walker, D.W. Behaviour and hippocampus-specific changes in spiny mouse neonates after treatment of the mother with the viral-mimetic Poly I:C at mid-pregnancy. Brain Behav. Immun. 2012, 26, 1288-1299. [CrossRef]

94. Esshili, A.; Manitz, M.P.; Freund, N.; Juckel, G. Induction of inducible nitric oxide synthase expression in activated microglia and astrocytes following pre- and postnatal immune challenge in an animal model of schizophrenia. Eur. Neuropsychopharmacol. 2020, 35, 100-110. [CrossRef] [PubMed]

95. Duchatel, R.J.; Meehan, C.L.; Harms, L.R.; Michie, P.T.; Bigland, M.J.; Smith, D.W.; Walker, F.R.; Jobling, P.; Hodgson, D.M.; Tooney, P.A. Late gestation immune activation increases IBA1-positive immunoreactivity levels in the corpus callosum of adult rat offspring. Psychiatry Res. 2018, 266, 175-185. [CrossRef]

96. Ding, S.; Hu, Y.; Luo, B.; Cai, Y.; Hao, K.; Yang, Y.; Zhang, Y.; Wang, X.; Ding, M.; Zhang, H.; et al. Age-related changes in neuroinflammation and prepulse inhibition in offspring of rats treated with Poly I:C in early gestation. Behav. Brain Funct. 2019, 15, 3. [CrossRef] 
97. Arsenault, D.; St-Amour, I.; Cisbani, G.; Rousseau, L.S.; Cicchetti, F. The different effects of LPS and poly I:C prenatal immune challenges on the behavior, development and inflammatory responses in pregnant mice and their offspring. Brain Behav. Immun. 2014, 38, 77-90. [CrossRef]

98. Giovanoli, S.; Weber-Stadlbauer, U.; Schedlowski, M.; Meyer, U.; Engler, H. Prenatal immune activation causes hippocampal synaptic deficits in the absence of overt microglia anomalies. Brain Behav. Immun. 2016, 55, 25-38. [CrossRef]

99. Giovanoli, S.; Notter, T.; Richetto, J.; Labouesse, M.A.; Vuillermot, S.; Riva, M.A.; Meyer, U. Late prenatal immune activation causes hippocampal deficits in the absence of persistent inflammation across aging. J. Neuroinflamm. 2015, 12, 221. [CrossRef]

100. Paylor, J.W.; Lins, B.R.; Greba, Q.; Moen, N.; de Moraes, R.S.; Howland, J.G.; Winship, I.R. Developmental disruption of perineuronal nets in the medial prefrontal cortex after maternal immune activation. Sci. Rep. 2016, 6, 37580. [CrossRef]

101. Sofroniew, M.V. Astrocyte Reactivity: Subtypes, States, and Functions in CNS Innate Immunity. Trends Immunol. 2020, 41, 758-770. [CrossRef]

102. Zeng, H.C.; Zhang, L.; Li, Y.Y.; Wang, Y.J.; Xia, W.; Lin, Y.; Wei, J.; Xu, S.Q. Inflammation-like glial response in rat brain induced by prenatal PFOS exposure. Neurotoxicology 2011, 32, 130-139. [CrossRef]

103. Bennett, G.A.; Palliser, H.K.; Shaw, J.C.; Walker, D.; Hirst, J.J. Prenatal Stress Alters Hippocampal Neuroglia and Increases Anxiety in Childhood. Dev. Neurosci. 2015, 37, 533-545. [CrossRef]

104. Sowa, J.E.; Slusarczyk, J.; Trojan, E.; Chamera, K.; Leskiewicz, M.; Regulska, M.; Kotarska, K.; Basta-Kaim, A. Prenatal stress affects viability, activation, and chemokine signaling in astroglial cultures. J. Neuroimmunol. 2017, 311, 79-87. [CrossRef] [PubMed]

105. Duran-Carabali, L.E.; Arcego, D.M.; Odorcyk, F.K.; Reichert, L.; Cordeiro, J.L.; Sanches, E.F.; Freitas, L.D.; Dalmaz, C.; Pagnussat, A.; Netto, C.A. Prenatal and Early Postnatal Environmental Enrichment Reduce Acute Cell Death and Prevent Neurodevelopment and Memory Impairments in Rats Submitted to Neonatal Hypoxia Ischemia. Mol. Neurobiol. 2018, 55, 3627-3641. [CrossRef] [PubMed]

106. Frahm, K.A.; Handa, R.J.; Tobet, S.A. Embryonic Exposure to Dexamethasone Affects Nonneuronal Cells in the Adult Paraventricular Nucleus of the Hypothalamus. J. Endocr. Soc. 2018, 2, 140-153. [CrossRef]

107. Mayordomo, F.; Renau-Piqueras, J.; Megias, L.; Guerri, C.; Iborra, F.J.; Azorin, I.; Ledig, M. Cytochemical and stereological analysis of rat cortical astrocytes during development in primary culture. Effect of prenatal exposure to ethanol. Int. J. Dev. Biol. 1992, 36, 311-321.

108. Onoda, A.; Takeda, K.; Umezawa, M. Pretreatment with N-acetyl cysteine suppresses chronic reactive astrogliosis following maternal nanoparticle exposure during gestational period. Nanotoxicology 2017, 11, 1012-1025. [CrossRef] [PubMed]

109. White, C.L.; Pistell, P.J.; Purpera, M.N.; Gupta, S.; Fernandez-Kim, S.O.; Hise, T.L.; Keller, J.N.; Ingram, D.K.; Morrison, C.D.; Bruce-Keller, A.J. Effects of high fat diet on Morris maze performance, oxidative stress, and inflammation in rats: Contributions of maternal diet. Neurobiol. Dis. 2009, 35, 3-13. [CrossRef] [PubMed]

110. Kim, D.W.; Glendining, K.A.; Grattan, D.R.; Jasoni, C.L. Maternal obesity leads to increased proliferation and numbers of astrocytes in the developing fetal and neonatal mouse hypothalamus. Int. J. Dev. Neurosci. Off. J. Int. Soc. Dev. Neurosci. 2016, 53, 18-25. [CrossRef]

111. Orellana, J.A.; Shoji, K.F.; Abudara, V.; Ezan, P.; Amigou, E.; Saez, P.J.; Jiang, J.X.; Naus, C.C.; Saez, J.C.; Giaume, C. Amyloid beta-induced death in neurons involves glial and neuronal hemichannels. J. Neurosci. Off. J. Soc. Neurosci. 2011, 31, $4962-4977$. [CrossRef]

112. Orellana, J.A.; Froger, N.; Ezan, P.; Jiang, J.X.; Bennett, M.V.; Naus, C.C.; Giaume, C.; Saez, J.C. ATP and glutamate released via astroglial connexin 43 hemichannels mediate neuronal death through activation of pannexin 1 hemichannels. J. Neurochem. 2011, 118, 826-840. [CrossRef]

113. Hu, J.; Ferreira, A.; Van Eldik, L.J. S100beta induces neuronal cell death through nitric oxide release from astrocytes. J. Neurochem. 1997, 69, 2294-2301. [CrossRef]

114. Abudara, V.; Roux, L.; Dallerac, G.; Matias, I.; Dulong, J.; Mothet, J.P.; Rouach, N.; Giaume, C. Activated microglia impairs neuroglial interaction by opening Cx43 hemichannels in hippocampal astrocytes. Glia 2015, 63, 795-811. [CrossRef]

115. Gajardo-Gomez, R.; Labra, V.C.; Maturana, C.J.; Shoji, K.F.; Santibanez, C.A.; Saez, J.C.; Giaume, C.; Orellana, J.A. Cannabinoids prevent the amyloid beta-induced activation of astroglial hemichannels: A neuroprotective mechanism. Glia 2017, 65, 122-137. [CrossRef] [PubMed]

116. Karpuk, N.; Burkovetskaya, M.; Fritz, T.; Angle, A.; Kielian, T. Neuroinflammation leads to region-dependent alterations in astrocyte gap junction communication and hemichannel activity. J. Neurosci. Off. J. Soc. Neurosci. 2011, 31, 414-425. [CrossRef] [PubMed]

117. Garre, J.M.; Yang, G.; Bukauskas, F.F.; Bennett, M.V. FGF-1 Triggers Pannexin-1 Hemichannel Opening in Spinal Astrocytes of Rodents and Promotes Inflammatory Responses in Acute Spinal Cord Slices. J. Neurosci. Off. J. Soc. Neurosci. 2016, 36, 4785-4801. [CrossRef]

118. Santiago, M.F.; Veliskova, J.; Patel, N.K.; Lutz, S.E.; Caille, D.; Charollais, A.; Meda, P.; Scemes, E. Targeting pannexin1 improves seizure outcome. PLoS ONE 2011, 6, e25178. [CrossRef]

119. Yi, C.; Mei, X.; Ezan, P.; Mato, S.; Matias, I.; Giaume, C.; Koulakoff, A. Astroglial connexin 43 contributes to neuronal suffering in a mouse model of Alzheimer's disease. Cell Death Differ. 2016, 23, 1691-1701. [CrossRef] 
120. Gajardo-Gomez, R.; Santibanez, C.A.; Labra, V.C.; Gomez, G.I.; Eugenin, E.A.; Orellana, J.A. HIV gp120 Protein Increases the Function of Connexin 43 Hemichannels and Pannexin-1 Channels in Astrocytes: Repercussions on Astroglial Function. Int. J. Mol. Sci. 2020, 21, 2503. [CrossRef] [PubMed]

121. Diaz, E.F.; Labra, V.C.; Alvear, T.F.; Mellado, L.A.; Inostroza, C.A.; Oyarzun, J.E.; Salgado, N.; Quintanilla, R.A.; Orellana, J.A. Connexin 43 hemichannels and pannexin-1 channels contribute to the alpha-synuclein-induced dysfunction and death of astrocytes. Glia 2019, 67, 1598-1619.

122. Gomez, G.I.; Falcon, R.V.; Maturana, C.J.; Labra, V.C.; Salgado, N.; Rojas, C.A.; Oyarzun, J.E.; Cerpa, W.; Quintanilla, R.A.; Orellana, J.A. Heavy Alcohol Exposure Activates Astroglial Hemichannels and Pannexons in the Hippocampus of Adolescent Rats: Effects on Neuroinflammation and Astrocyte Arborization. Front. Cell Neurosci. 2018, 12, 472. [CrossRef]

123. Saez, J.C.; Leybaert, L. Hunting for connexin hemichannels. FEBS Lett. 2014, 588, 1205-1211. [CrossRef] [PubMed]

124. Saez, J.C.; Berthoud, V.M.; Branes, M.C.; Martinez, A.D.; Beyer, E.C. Plasma membrane channels formed by connexins: Their regulation and functions. Physiol. Rev. 2003, 83, 1359-1400. [CrossRef]

125. Leybaert, L.; Lampe, P.D.; Dhein, S.; Kwak, B.R.; Ferdinandy, P.; Beyer, E.C.; Laird, D.W.; Naus, C.C.; Green, C.R.; Schulz, R Connexins in Cardiovascular and Neurovascular Health and Disease: Pharmacological Implications. Pharm. Rev. 2017, 69, 396-478. [CrossRef] [PubMed]

126. Paul, D.L.; Ebihara, L.; Takemoto, L.J.; Swenson, K.I.; Goodenough, D.A. Connexin46, a novel lens gap junction protein, induces voltage-gated currents in nonjunctional plasma membrane of Xenopus oocytes. J. Cell Biol. 1991, 115, 1077-1089. [CrossRef]

127. Dahl, G. The Pannexin1 membrane channel: Distinct conformations and functions. FEBS Lett. 2018, 592, 3201-3209. [CrossRef] [PubMed]

128. Syrjanen, J.; Michalski, K.; Kawate, T.; Furukawa, H. On the molecular nature of large-pore channels. J. Mol. Biol. 2021, 433, 166994. [CrossRef]

129. Patel, D.; Zhang, X.; Veenstra, R.D. Connexin hemichannel and pannexin channel electrophysiology: How do they differ? FEBS Lett. 2014, 588, 1372-1378. [CrossRef]

130. Giaume, C.; Naus, C.C.; Saez, J.C.; Leybaert, L. Glial Connexins and Pannexins in the Healthy and Diseased Brain. Physiol. Rev. 2021, 101, 93-145. [CrossRef] [PubMed]

131. Bruzzone, R.; Hormuzdi, S.G.; Barbe, M.T.; Herb, A.; Monyer, H. Pannexins, a family of gap junction proteins expressed in brain. Proc. Natl. Acad. Sci. USA 2003, 100, 13644-13649. [CrossRef] [PubMed]

132. Chever, O.; Lee, C.Y.; Rouach, N. Astroglial connexin43 hemichannels tune basal excitatory synaptic transmission. J. Neurosci. Off. J. Soc. Neurosci. 2014, 34, 11228-11232. [CrossRef]

133. Ma, W.; Compan, V.; Zheng, W.; Martin, E.; North, R.A.; Verkhratsky, A.; Surprenant, A. Pannexin 1 forms an anion-selective channel. Pflug. Arch. Eur. J. Physiol. 2012, 463, 585-592. [CrossRef]

134. Chiu, Y.H.; Jin, X.; Medina, C.B.; Leonhardt, S.A.; Kiessling, V.; Bennett, B.C.; Shu, S.; Tamm, L.K.; Yeager, M.; Ravichandran, K.S.; et al. A quantized mechanism for activation of pannexin channels. Nat. Commun. 2017, 8, 14324. [CrossRef]

135. Contreras, J.E.; Saez, J.C.; Bukauskas, F.F.; Bennett, M.V. Gating and regulation of connexin 43 (Cx43) hemichannels. Proc. Natl. Acad. Sci. USA 2003, 100, 11388-11393. [CrossRef]

136. Bao, L.; Locovei, S.; Dahl, G. Pannexin membrane channels are mechanosensitive conduits for ATP. FEBS Lett. 2004, 572, 65-68. [CrossRef]

137. Ebihara, L.; Liu, X.; Pal, J.D. Effect of external magnesium and calcium on human connexin46 hemichannels. Biophys. J. 2003, 84, 277-286. [CrossRef]

138. Bruzzone, R.; Barbe, M.T.; Jakob, N.J.; Monyer, H. Pharmacological properties of homomeric and heteromeric pannexin hemichannels expressed in Xenopus oocytes. J. Neurochem. 2005, 92, 1033-1043. [CrossRef]

139. Giaume, C.; Fromaget, C.; el Aoumari, A.; Cordier, J.; Glowinski, J.; Gros, D. Gap junctions in cultured astrocytes: Single-channel currents and characterization of channel-forming protein. Neuron 1991, 6, 133-143. [CrossRef]

140. Contreras, J.E.; Sanchez, H.A.; Eugenin, E.A.; Speidel, D.; Theis, M.; Willecke, K.; Bukauskas, F.F.; Bennett, M.V.; Saez, J.C. Metabolic inhibition induces opening of unapposed connexin 43 gap junction hemichannels and reduces gap junctional communication in cortical astrocytes in culture. Proc. Natl. Acad. Sci. USA 2002, 99, 495-500. [CrossRef] [PubMed]

141. Iglesias, R.; Dahl, G.; Qiu, F.; Spray, D.C.; Scemes, E. Pannexin 1: The molecular substrate of astrocyte "hemichannels". J. Neurosci. Off. J. Soc. Neurosci. 2009, 29, 7092-7097. [CrossRef]

142. Kang, J.; Kang, N.; Lovatt, D.; Torres, A.; Zhao, Z.; Lin, J.; Nedergaard, M. Connexin 43 hemichannels are permeable to ATP. J. Neurosci. Off. J. Soc. Neurosci. 2008, 28, 4702-4711. [CrossRef]

143. Pan, H.C.; Chou, Y.C.; Sun, S.H. P2X7 R-mediated Ca(2+) -independent d-serine release via pannexin-1 of the P2X7 R-pannexin-1 complex in astrocytes. Glia 2015, 63, 877-893. [CrossRef]

144. Roux, L.; Madar, A.; Lacroix, M.M.; Yi, C.; Benchenane, K.; Giaume, C. Astroglial Connexin 43 Hemichannels Modulate Olfactory Bulb Slow Oscillations. J. Neurosci. Off. J. Soc. Neurosci. 2015, 35, 15339-15352. [CrossRef]

145. Alvarez, A.; Lagos-Cabre, R.; Kong, M.; Cardenas, A.; Burgos-Bravo, F.; Schneider, P.; Quest, A.F.; Leyton, L. Integrin-mediated transactivation of P2X7R via hemichannel-dependent ATP release stimulates astrocyte migration. Biochim. Biophys. Acta 2016, 1863, 2175-2188. [CrossRef]

146. Guillebaud, F.; Barbot, M.; Barbouche, R.; Brezun, J.M.; Poirot, K.; Vasile, F.; Lebrun, B.; Rouach, N.; Dallaporta, M.; Gaige, S.; et al. Blockade of Glial Connexin 43 Hemichannels Reduces Food Intake. Cells 2020, 9, 2387. [CrossRef] [PubMed] 
147. Meunier, C.; Wang, N.; Yi, C.; Dallerac, G.; Ezan, P.; Koulakoff, A.; Leybaert, L.; Giaume, C. Contribution of Astroglial Cx43 Hemichannels to the Modulation of Glutamatergic Currents by D-Serine in the Mouse Prefrontal Cortex. J. Neurosci. Off. J. Soc. Neurosci. 2017, 37, 9064-9075. [CrossRef] [PubMed]

148. Ardiles, A.O.; Flores-Munoz, C.; Toro-Ayala, G.; Cardenas, A.M.; Palacios, A.G.; Munoz, P.; Fuenzalida, M.; Saez, J.C.; Martinez, A.D. Pannexin 1 regulates bidirectional hippocampal synaptic plasticity in adult mice. Front. Cell Neurosci. 2014, 8, 326. [CrossRef] [PubMed]

149. Prochnow, N.; Abdulazim, A.; Kurtenbach, S.; Wildforster, V.; Dvoriantchikova, G.; Hanske, J.; Petrasch-Parwez, E.; Shestopalov, V.I.; Dermietzel, R.; Manahan-Vaughan, D.; et al. Pannexin1 stabilizes synaptic plasticity and is needed for learning. PLoS ONE 2012, 7, e51767. [CrossRef]

150. Walrave, L.; Vinken, M.; Albertini, G.; De Bundel, D.; Leybaert, L.; Smolders, I.J. Inhibition of Connexin43 Hemichannels Impairs Spatial Short-Term Memory without Affecting Spatial Working Memory. Front. Cell Neurosci. 2016, 10, 288. [CrossRef]

151. Stehberg, J.; Moraga-Amaro, R.; Salazar, C.; Becerra, A.; Echeverria, C.; Orellana, J.A.; Bultynck, G.; Ponsaerts, R.; Leybaert, L.; Simon, F.; et al. Release of gliotransmitters through astroglial connexin 43 hemichannels is necessary for fear memory consolidation in the basolateral amygdala. FASEB J. 2012, 26, 3649-3657. [CrossRef] [PubMed]

152. Retamal, M.A.; Froger, N.; Palacios-Prado, N.; Ezan, P.; Saez, P.J.; Saez, J.C.; Giaume, C. Cx43 hemichannels and gap junction channels in astrocytes are regulated oppositely by proinflammatory cytokines released from activated microglia. J. Neurosci. Off. J. Soc. Neurosci. 2007, 27, 13781-13792. [CrossRef]

153. Fukuyama, K.; Ueda, Y.; Okada, M. Effects of Carbamazepine, Lacosamide and Zonisamide on Gliotransmitter Release Associated with Activated Astroglial Hemichannels. Pharmaceuticals 2020, 13, 117. [CrossRef] [PubMed]

154. Wei, H.; Deng, F.; Chen, Y.; Qin, Y.; Hao, Y.; Guo, X. Ultrafine carbon black induces glutamate and ATP release by activating connexin and pannexin hemichannels in cultured astrocytes. Toxicology 2014, 323, 32-41. [CrossRef] [PubMed]

155. Retamal, M.A.; Cortes, C.J.; Reuss, L.; Bennett, M.V.; Saez, J.C. S-nitrosylation and permeation through connexin 43 hemichannels in astrocytes: Induction by oxidant stress and reversal by reducing agents. Proc. Natl. Acad. Sci. USA 2006, 103, 4475-4480. [CrossRef]

156. O'Carroll, S.J.; Alkadhi, M.; Nicholson, L.F.; Green, C.R. Connexin 43 mimetic peptides reduce swelling, astrogliosis, and neuronal cell death after spinal cord injury. Cell Commun. Adhes. 2008, 15, 27-42. [CrossRef]

157. Fiori, M.C.; Figueroa, V.; Zoghbi, M.E.; Saez, J.C.; Reuss, L.; Altenberg, G.A. Permeation of calcium through purified connexin 26 hemichannels. J. Biol. Chem. 2012, 287, 40826-40834. [CrossRef]

158. Schalper, K.A.; Sanchez, H.A.; Lee, S.C.; Altenberg, G.A.; Nathanson, M.H.; Saez, J.C. Connexin 43 hemichannels mediate the $\mathrm{Ca}^{2+}$ influx induced by extracellular alkalinization. Am. J. Physiol. Cell Physiol. 2010, 299, C1504-C1515. [CrossRef]

159. Locovei, S.; Wang, J.; Dahl, G. Activation of pannexin 1 channels by ATP through P2Y receptors and by cytoplasmic calcium. FEBS Lett. 2006, 580, 239-244. [CrossRef] [PubMed]

160. Kim, J.C.; Perez-Hernandez, M.; Alvarado, F.J.; Maurya, S.R.; Montnach, J.; Yin, Y.; Zhang, M.; Lin, X.; Vasquez, C.; Heguy, A.; et al. Disruption of $\mathrm{Ca}(2+)$ i Homeostasis and Connexin 43 Hemichannel Function in the Right Ventricle Precedes Overt Arrhythmogenic Cardiomyopathy in Plakophilin-2-Deficient Mice. Circulation 2019, 140, 1015-1030. [CrossRef]

161. Yi, C.; Ezan, P.; Fernandez, P.; Schmitt, J.; Saez, J.C.; Giaume, C.; Koulakoff, A. Inhibition of glial hemichannels by boldine treatment reduces neuronal suffering in a murine model of Alzheimer's disease. Glia 2017, 65, 1607-1625. [CrossRef] [PubMed]

162. Walrave, L.; Pierre, A.; Albertini, G.; Aourz, N.; De Bundel, D.; Van Eeckhaut, A.; Vinken, M.; Giaume, C.; Leybaert, L.; Smolders, I. Inhibition of astroglial connexin43 hemichannels with TAT-Gap19 exerts anticonvulsant effects in rodents. Glia 2018, 66, 1788-1804. [CrossRef]

163. Wellmann, M.; Alvarez-Ferradas, C.; Maturana, C.J.; Saez, J.C.; Bonansco, C. Astroglial Ca(2+)-Dependent Hyperexcitability Requires P2Y1 Purinergic Receptors and Pannexin-1 Channel Activation in a Chronic Model of Epilepsy. Front. Cell Neurosci. 2018, 12, 446. [CrossRef]

164. Orellana, J.A.; Saez, J.C.; Bennett, M.V.; Berman, J.W.; Morgello, S.; Eugenin, E.A. HIV increases the release of dickkopf-1 protein from human astrocytes by a Cx43 hemichannel-dependent mechanism. J. Neurochem. 2014, 128, 752-763. [CrossRef]

165. Berman, J.W.; Carvallo, L.; Buckner, C.M.; Luers, A.; Prevedel, L.; Bennett, M.V.; Eugenin, E.A. HIV-tat alters Connexin43 expression and trafficking in human astrocytes: Role in NeuroAIDS. J. Neuroinflamm. 2016, 13, 54. [CrossRef] [PubMed]

166. Chen, B.; Yang, L.; Chen, J.; Chen, Y.; Zhang, L.; Wang, L.; Li, X.; Li, Y.; Yu, H. Inhibition of Connexin 43 hemichannels with Gap19 protects cerebral ischemia/reperfusion injury via the JAK2/STAT3 pathway in mice. Brain Res. Bull. 2019, 146, 124-135. [CrossRef]

167. Freitas-Andrade, M.; Wang, N.; Bechberger, J.F.; De Bock, M.; Lampe, P.D.; Leybaert, L.; Naus, C.C. Targeting MAPK phosphorylation of Connexin43 provides neuroprotection in stroke. J. Exp. Med. 2019, 216, 916-935. [CrossRef]

168. Yu, H.; Cao, X.; Li, W.; Liu, P.; Zhao, Y.; Song, L.; Chen, J.; Chen, B.; Yu, W.; Xu, Y. Targeting connexin 43 provides anti-inflammatory effects after intracerebral hemorrhage injury by regulating YAP signaling. J. Neuroinflamm. 2020, 17, 322. [CrossRef]

169. Mao, Y.; Tonkin, R.S.; Nguyen, T.; O'Carroll, S.J.; Nicholson, L.F.; Green, C.R.; Moalem-Taylor, G.; Gorrie, C.A. Systemic Administration of Connexin43 Mimetic Peptide Improves Functional Recovery after Traumatic Spinal Cord Injury in Adult Rats. J. Neurotrauma 2017, 34, 707-719. [CrossRef] 
170. Avendano, B.C.; Montero, T.D.; Chavez, C.E.; von Bernhardi, R.; Orellana, J.A. Prenatal exposure to inflammatory conditions increases Cx43 and Panx1 unopposed channel opening and activation of astrocytes in the offspring effect on neuronal survival. Glia 2015, 63, 2058-2072. [CrossRef] [PubMed]

171. De Vuyst, E.; Decrock, E.; De Bock, M.; Yamasaki, H.; Naus, C.C.; Evans, W.H.; Leybaert, L. Connexin hemichannels and gap junction channels are differentially influenced by lipopolysaccharide and basic fibroblast growth factor. Mol. Biol. Cell 2007, 18, 34-46. [CrossRef]

172. Saez, J.C.; Vargas, A.A.; Hernandez, D.E.; Ortiz, F.C.; Giaume, C.; Orellana, J.A. Permeation of Molecules through Astroglial Connexin 43 Hemichannels Is Modulated by Cytokines with Parameters Depending on the Permeant Species. Int. J. Mol. Sci. 2020, 21, 3970 .

173. Vinken, M. Regulation of connexin signaling by the epigenetic machinery. Biochim. Biophys. Acta 2016, 1859, 262-268. [CrossRef] [PubMed]

174. Chavez, C.E.; Oyarzun, J.E.; Avendano, B.C.; Mellado, L.A.; Inostroza, C.A.; Alvear, T.F.; Orellana, J.A. The Opening of Connexin 43 Hemichannels Alters Hippocampal Astrocyte Function and Neuronal Survival in Prenatally LPS-Exposed Adult Offspring Front. Cell Neurosci. 2019, 13, 460. [CrossRef] [PubMed]

175. Da Silva, J.; Pierrat, B.; Mary, J.L.; Lesslauer, W. Blockade of p38 mitogen-activated protein kinase pathway inhibits inducible nitric-oxide synthase expression in mouse astrocytes. J. Biol. Chem. 1997, 272, 28373-28380. [CrossRef] [PubMed]

176. Ding, M.; St Pierre, B.A.; Parkinson, J.F.; Medberry, P.; Wong, J.L.; Rogers, N.E.; Ignarro, L.J.; Merrill, J.E. Inducible nitric-oxide synthase and nitric oxide production in human fetal astrocytes and microglia. A kinetic analysis. J. Biol. Chem. 1997, 272, 11327-11335. [CrossRef] [PubMed]

177. Chamera, K.; Kotarska, K.; Szuster-Gluszczak, M.; Trojan, E.; Skorkowska, A.; Pomierny, B.; Krzyzanowska, W.; Bryniarska, N.; Basta-Kaim, A. The prenatal challenge with lipopolysaccharide and polyinosinic:polycytidylic acid disrupts CX3CL1-CX3CR1 and CD200-CD200R signalling in the brains of male rat offspring: A link to schizophrenia-like behaviours. J. Neuroinflamm. 2020, 17, 247. [CrossRef]

178. Tellez-Merlo, G.; Morales-Medina, J.C.; Camacho-Abrego, I.; Juarez-Diaz, I.; Aguilar-Alonso, P.; de la Cruz, F.; Iannitti, T.; Flores, G. Prenatal immune challenge induces behavioral deficits, neuronal remodeling, and increases brain nitric oxide and zinc levels in the male rat offspring. Neuroscience 2019, 406, 594-605. [CrossRef]

179. Lohman, A.W.; Weaver, J.L.; Billaud, M.; Sandilos, J.K.; Griffiths, R.; Straub, A.C.; Penuela, S.; Leitinger, N.; Laird, D.W.; Bayliss, D.A.; et al. S-nitrosylation inhibits pannexin 1 channel function. J. Biol. Chem. 2012, 287, 39602-39612. [CrossRef] [PubMed]

180. Poornima, V.; Vallabhaneni, S.; Mukhopadhyay, M.; Bera, A.K. Nitric oxide inhibits the pannexin 1 channel through a cGMP-PKG dependent pathway. Nitric Oxide Biol. Chem. Off. J. Nitric Oxide Soc. 2015, 47, 77-84. [CrossRef] [PubMed]

181. Baroja-Mazo, A.; Barbera-Cremades, M.; Pelegrin, P. The participation of plasma membrane hemichannels to purinergic signaling. Biochim. Biophys. Acta 2013, 1828, 79-93. [CrossRef]

182. Pelegrin, P.; Surprenant, A. Pannexin-1 mediates large pore formation and interleukin-1beta release by the ATP-gated P2X7 receptor. EMBO J. 2006, 25, 5071-5082. [CrossRef]

183. Poornima, V.; Madhupriya, M.; Kootar, S.; Sujatha, G.; Kumar, A.; Bera, A.K. P2X7 receptor-pannexin 1 hemichannel association: Effect of extracellular calcium on membrane permeabilization. J. Mol. Neurosci. MN 2012, 46, 585-594. [CrossRef]

184. Iglesias, R.; Locovei, S.; Roque, A.; Alberto, A.P.; Dahl, G.; Spray, D.C.; Scemes, E. P2X7 receptor-Pannexin1 complex: Pharmacology and signaling. Am. J. Physiol. Cell Physiol. 2008, 295, C752-C760. [CrossRef] [PubMed]

185. Sorge, R.E.; Trang, T.; Dorfman, R.; Smith, S.B.; Beggs, S.; Ritchie, J.; Austin, J.S.; Zaykin, D.V.; Vander Meulen, H.; Costigan, M.; et al. Genetically determined P2X7 receptor pore formation regulates variability in chronic pain sensitivity. Nat. Med. 2012, 18, 595-599. [CrossRef]

186. Qiu, F.; Dahl, G. A permeant regulating its permeation pore: Inhibition of pannexin 1 channels by ATP. Am. J. Physiol. Cell Physiol. 2009, 296, C250-C255. [CrossRef] [PubMed]

187. Ventura, L.; Freiberger, V.; Thiesen, V.B.; Dias, P.; Dutra, M.L.; Silva, B.B.; Schlindwein, A.D.; Comim, C.M. Involvement of NLRP3 inflammasome in schizophrenia-like behaviour in young animals after maternal immune activation. Acta Neuropsychiatr. 2020, 32, 321-327. [CrossRef] [PubMed]

188. Kanneganti, T.D.; Lamkanfi, M.; Kim, Y.G.; Chen, G.; Park, J.H.; Franchi, L.; Vandenabeele, P.; Nunez, G. Pannexin-1-mediated recognition of bacterial molecules activates the cryopyrin inflammasome independent of Toll-like receptor signaling. Immunity 2007, 26, 433-443. [CrossRef] [PubMed]

189. Minkiewicz, J.; de Rivero Vaccari, J.P.; Keane, R.W. Human astrocytes express a novel NLRP2 inflammasome. Glia 2013, 61, 1113-1121. [CrossRef]

190. Murphy, N.; Cowley, T.R.; Richardson, J.C.; Virley, D.; Upton, N.; Walter, D.; Lynch, M.A. The neuroprotective effect of a specific P2X(7) receptor antagonist derives from its ability to inhibit assembly of the NLRP3 inflammasome in glial cells. Brain Pathol. 2012, 22, 295-306. [CrossRef]

191. Silverman, W.R.; de Rivero Vaccari, J.P.; Locovei, S.; Qiu, F.; Carlsson, S.K.; Scemes, E.; Keane, R.W.; Dahl, G. The pannexin 1 channel activates the inflammasome in neurons and astrocytes. J. Biol. Chem. 2009, 284, 18143-18151. [CrossRef] [PubMed]

192. De Bock, M.; Wang, N.; Bol, M.; Decrock, E.; Ponsaerts, R.; Bultynck, G.; Dupont, G.; Leybaert, L. Connexin 43 hemichannels contribute to cytoplasmic $\mathrm{Ca}^{2+}$ oscillations by providing a bimodal $\mathrm{Ca}^{2+}$-dependent $\mathrm{Ca}^{2+}$ entry pathway. J. Biol. Chem. 2012, 287, 12250-12266. [CrossRef] 
193. Lopez, X.; Palacios-Prado, N.; Guiza, J.; Escamilla, R.; Fernandez, P.; Vega, J.L.; Rojas, M.; Marquez-Miranda, V.; Chamorro, E.; Cardenas, A.M.; et al. A physiologic rise in cytoplasmic calcium ion signal increases pannexin1 channel activity via a C-terminus phosphorylation by CaMKII. Proc. Natl. Acad. Sci. USA 2021, 118, e2108967118. [CrossRef] [PubMed]

194. Kelley, M.H.; Wu, W.W.; Lei, J.; McLane, M.; Xie, H.; Hart, K.D.; Pereira, L.; Burd, I.; Maylie, J. Functional changes in hippocampal synaptic signaling in offspring survivors of a mouse model of intrauterine inflammation. J. Neuroinflamm. 2017, 14, 180. [CrossRef] [PubMed]

195. Panatier, A.; Robitaille, R. Astrocytic mGluR5 and the tripartite synapse. Neuroscience 2016, 323, 29-34. [CrossRef]

196. Rovegno, M.; Soto, P.A.; Saez, P.J.; Naus, C.C.; Saez, J.C.; von Bernhardi, R. Connexin 43 hemichannels mediate secondary cellular damage spread from the trauma zone to distal zones in astrocyte monolayers. Glia 2015, 63, 1185-1199. [CrossRef]

197. Albalawi, F.; Lu, W.; Beckel, J.M.; Lim, J.C.; McCaughey, S.A.; Mitchell, C.H. The P2X7 Receptor Primes IL-1beta and the NLRP3 Inflammasome in Astrocytes Exposed to Mechanical Strain. Front. Cell Neurosci. 2017, 11, 227. [CrossRef]

198. Wei, L.; Sheng, H.; Chen, L.; Hao, B.; Shi, X.; Chen, Y. Effect of pannexin-1 on the release of glutamate and cytokines in astrocytes. J. Clin. Neurosci. 2016, 23, 135-141. [CrossRef]

199. Agulhon, C.; Sun, M.Y.; Murphy, T.; Myers, T.; Lauderdale, K.; Fiacco, T.A. Calcium Signaling and Gliotransmission in Normal vs. Reactive Astrocytes. Front. Pharm. 2012, 3, 139. [CrossRef]

200. Ishikawa, M.; Iwamoto, T.; Nakamura, T.; Doyle, A.; Fukumoto, S.; Yamada, Y. Pannexin 3 functions as an ER Ca(2+) channel, hemichannel, and gap junction to promote osteoblast differentiation. J. Cell Biol. 2011, 193, 1257-1274. [CrossRef]

201. Vanden Abeele, F.; Bidaux, G.; Gordienko, D.; Beck, B.; Panchin, Y.V.; Baranova, A.V.; Ivanov, D.V.; Skryma, R.; Prevarskaya, N. Functional implications of calcium permeability of the channel formed by pannexin 1. J. Cell Biol. 2006, 174, 535-546. [CrossRef] [PubMed]

202. Yang, Y.; Delalio, L.J.; Best, A.K.; Macal, E.; Milstein, J.; Donnelly, I.; Miller, A.M.; McBride, M.; Shu, X.; Koval, M.; et al. Endothelial Pannexin 1 Channels Control Inflammation by Regulating Intracellular Calcium. J. Immunol. 2020, 204, 2995-3007. [CrossRef]

203. Abudara, V.; Bechberger, J.; Freitas-Andrade, M.; De Bock, M.; Wang, N.; Bultynck, G.; Naus, C.C.; Leybaert, L.; Giaume, C. The connexin43 mimetic peptide Gap19 inhibits hemichannels without altering gap junctional communication in astrocytes. Front. Cell Neurosci. 2014, 8, 306. [CrossRef]

204. Maatouk, L.; Yi, C.; Carrillo-de Sauvage, M.A.; Compagnion, A.C.; Hunot, S.; Ezan, P.; Hirsch, E.C.; Koulakoff, A.; Pfrieger, F.W.; Tronche, F.; et al. Glucocorticoid receptor in astrocytes regulates midbrain dopamine neurodegeneration through connexin hemichannel activity. Cell Death Differ. 2019, 26, 580-596. [CrossRef]

205. Alberdi, E.; Sanchez-Gomez, M.V.; Matute, C. Calcium and glial cell death. Cell Calcium 2005, 38, 417-425. [CrossRef] [PubMed]

206. Bernardi, P.; Rasola, A. Calcium and cell death: The mitochondrial connection. Sub-Cell. Biochem. 2007, 45, 481-506.

207. Brustovetsky, N.; Brustovetsky, T.; Jemmerson, R.; Dubinsky, J.M. Calcium-induced cytochrome c release from CNS mitochondria is associated with the permeability transition and rupture of the outer membrane. J. Neurochem. 2002, 80, 207-218. [CrossRef]

208. Islam, M.R.; Uramoto, H.; Okada, T.; Sabirov, R.Z.; Okada, Y. Maxi-anion channel and pannexin 1 hemichannel constitute separate pathways for swelling-induced ATP release in murine L929 fibrosarcoma cells. Am. J. Physiol. Cell Physiol. 2012, 303, C924-C935. [CrossRef]

209. Chen, K.W.; Demarco, B.; Heilig, R.; Shkarina, K.; Boettcher, A.; Farady, C.J.; Pelczar, P.; Broz, P. Extrinsic and intrinsic apoptosis activate pannexin-1 to drive NLRP3 inflammasome assembly. EMBO J. 2019, 38, e101638. [CrossRef]

210. Yang, D.; He, Y.; Munoz-Planillo, R.; Liu, Q.; Nunez, G. Caspase-11 Requires the Pannexin-1 Channel and the Purinergic P2X7 Pore to Mediate Pyroptosis and Endotoxic Shock. Immunity 2015, 43, 923-932. [CrossRef] [PubMed]

211. Mellstrom, B.; Savignac, M.; Gomez-Villafuertes, R.; Naranjo, J.R. Ca ${ }^{2+}$-operated transcriptional networks: Molecular mechanisms and in vivo models. Physiol. Rev. 2008, 88, 421-449. [CrossRef]

212. Perez-Nievas, B.G.; Serrano-Pozo, A. Deciphering the Astrocyte Reaction in Alzheimer's Disease. Front. Aging Neurosci. 2018, 10, 114. [CrossRef]

213. Lante, F.; Meunier, J.; Guiramand, J.; De Jesus Ferreira, M.C.; Cambonie, G.; Aimar, R.; Cohen-Solal, C.; Maurice, T.; Vignes, M.; Barbanel, G. Late N-acetylcysteine treatment prevents the deficits induced in the offspring of dams exposed to an immune stress during gestation. Hippocampus 2008, 18, 602-609. [CrossRef] [PubMed]

214. Luo, L.; O'Leary, D.D. Axon retraction and degeneration in development and disease. Annu Rev. Neurosci. 2005, 28, 127-156. [CrossRef] [PubMed]

215. Riccomagno, M.M.; Kolodkin, A.L. Sculpting neural circuits by axon and dendrite pruning. Annu. Rev. Cell Dev. Biol. 2015, 31, 779-805. [CrossRef]

216. Fernandez de Cossio, L.; Guzman, A.; van der Veldt, S.; Luheshi, G.N. Prenatal infection leads to ASD-like behavior and altered synaptic pruning in the mouse offspring. Brain Behav. Immun. 2017, 63, 88-98. [CrossRef]

217. Monte, A.S.; Mello, B.S.F.; Borella, V.C.M.; da Silva Araujo, T.; da Silva, F.E.R.; Sousa, F.C.F.; de Oliveira, A.C.P.; Gama, C.S.; Seeman, M.V.; Vasconcelos, S.M.M.; et al. Two-hit model of schizophrenia induced by neonatal immune activation and peripubertal stress in rats: Study of sex differences and brain oxidative alterations. Behav. Brain Res. 2017, 331, 30-37. [CrossRef] [PubMed]

218. Thompson, R.J.; Jackson, M.F.; Olah, M.E.; Rungta, R.L.; Hines, D.J.; Beazely, M.A.; MacDonald, J.F.; MacVicar, B.A. Activation of pannexin-1 hemichannels augments aberrant bursting in the hippocampus. Science 2008, 322, 1555-1559. [CrossRef] 
219. Thompson, R.J.; Zhou, N.; MacVicar, B.A. Ischemia opens neuronal gap junction hemichannels. Science 2006, 312, 924-927. [CrossRef]

220. Schock, S.C.; Leblanc, D.; Hakim, A.M.; Thompson, C.S. ATP release by way of connexin 36 hemichannels mediates ischemic tolerance in vitro. Biochem. Biophys. Res. Commun. 2008, 368, 138-144. [CrossRef]

221. Hansen, D.B.; Ye, Z.C.; Calloe, K.; Braunstein, T.H.; Hofgaard, J.P.; Ransom, B.R.; Nielsen, M.S.; MacAulay, N. Activation, permeability, and inhibition of astrocytic and neuronal large pore (hemi)channels. J. Biol. Chem. 2014, 289, 26058-26073. [CrossRef] [PubMed]

222. Weilinger, N.L.; Lohman, A.W.; Rakai, B.D.; Ma, E.M.; Bialecki, J.; Maslieieva, V.; Rilea, T.; Bandet, M.V.; Ikuta, N.T.; Scott, L.; et al. Metabotropic NMDA receptor signaling couples Src family kinases to pannexin-1 during excitotoxicity. Nat. Neurosci. 2016, 19, 432-442. [CrossRef] [PubMed]

223. Weilinger, N.L.; Tang, P.L.; Thompson, R.J. Anoxia-induced NMDA receptor activation opens pannexin channels via Src family kinases. J. Neurosci. Off. J. Soc. Neurosci. 2012, 32, 12579-12588. [CrossRef] [PubMed]

224. Bialecki, J.; Werner, A.; Weilinger, N.L.; Tucker, C.M.; Vecchiarelli, H.A.; Egana, J.; Mendizabal-Zubiaga, J.; Grandes, P.; Hill, M.N.; Thompson, R.J. Suppression of Presynaptic Glutamate Release by Postsynaptic Metabotropic NMDA Receptor Signalling to Pannexin-1. J. Neurosci. Off. J. Soc. Neurosci. 2020, 40, 729-742. [CrossRef] [PubMed]

225. Engelhardt, B.; Vajkoczy, P.; Weller, R.O. The movers and shapers in immune privilege of the CNS. Nat. Immunol. 2017, 18, 123-131. [CrossRef]

226. Forrester, J.V.; McMenamin, P.G.; Dando, S.J. CNS infection and immune privilege. Nat. Rev. Neurosci. $2018,19,655-671$. [CrossRef]

227. Ransohoff, R.M.; Brown, M.A. Innate immunity in the central nervous system. J. Clin. Investig. 2012, 122, 1164-1171. [CrossRef]

228. Orellana, J.A.; Busso, D.; Ramirez, G.; Campos, M.; Rigotti, A.; Eugenin, J.; von Bernhardi, R. Prenatal nicotine exposure enhances Cx43 and Panx1 unopposed channel activity in brain cells of adult offspring mice fed a high-fat/cholesterol diet. Front. Cell Neurosci. 2014, 8, 403. [CrossRef]

229. Maturana, C.J.; Aguirre, A.; Saez, J.C. High glucocorticoid levels during gestation activate the inflammasome in hippocampal oligodendrocytes of the offspring. Dev. Neurobiol. 2017, 77, 625-642. [CrossRef] 